\title{
Mindetavlerne i Bjolderup Kirke.
}

Af Jes Sarup.

Naar man kommer ind i Bjolderup Kirke, er noget af det. første, man lægger Mærke til, en tredelt Tavle, som er anbragt lige overfor Indgangsdøren.

Paa Tavlerne er anbragt Navnene paa tre af Sognets Medlemmer, som er faldne $i$ den tysk-franske Krig 1870-71, nemlig Jens Andersen Jensen, født i Gammelby den 2. 8. 1837, død foran Metz 18. 10. 1870, Andreas Andresen, født i Scheldewick 5. 12. 1835, saaret foran Albervilliers 18. 1. 1871, død i Dannemarie 19. 1. 1871, Jes Hansen Paulsen, født i Smedager 10. 1. 1847, saaret for Metz 18. 8. 1870, død i Nieder-Ingelheim 8. 9. 1870. Tavlerne har iøvrigt samme Ordlyd. Ovenover hvert af Navnene staar: "Af dette Sogn døde for Konge og Fædreland«. Efter deres Dødsdato: "Elsket af mange har en Deel af Sognets Beboere sat Dig dette Minde. Dybt føles Dit Savn og længe vil Du mindes af Dine kjære, hvil i Fred! 2. Thim. 4. Capt. 7-8.« (Jeg har stridt den gode Strid, fuldkommet Løbet, bevaret Troen. Iøvrigt er Retfærdighedens Krone henlagt til mig, hvilken Herren, den retfærdige Dommer, skal give mig paa hin Dag, og ikke alene mig, men ogsaa alle dem, som har elsket hans herlige Aabenbarelse.) Der er den Ejendommelighed, at man har skrevet Byens Navn Skeldevig paa tysk paa Andreas Andresens Tavle, skønt han var af dansk Slægt, og paa Paulsens Tavle er hans Fødeby Smedager skrevet paa dansk. Da han var en Søn af en Hjemmetysker, kunde man have ventet, at den tyske Skrivemaade "Schmedagger" var bleven benyttet.

For de nulevende vil det forekomme noget ejendommeligt, at det.langt overvejende dansksindede Bjolderup Sogn skulde have anbragt disse Mindetavler $i$ Kirken for Mænd af deres Midte, der kun 6 Aar efter den voldelige Fraskillelse fra vort gamle Fædreland nu var tvungen med ud i Kampen mod et Folk, som vi ikke kunde have noget udestaaende med, men hvis Hersker tværtimod ved Prager-Fredsslutningen havde 
faaet indføjet den bekendte $\$ 5$, der gav Nordslesvig Ret til at vende tilbage til Danmark, saafremt en fri Afstemning blandt Beboerne gav Flertal herfor. Det var ogsaa langt fra Menigheden eller dennes lovlige Repræsentanter, der havde anbragt Tavlen, men tværtimod blev den ophængt paa Trods af Kirkeforstanderskabets Vilje og førte senere til de 4 Kirkeældstes Afskedigelse, og ikke nok hermed, men de blev yderligere idømt Fængselsstraf.

Man kan ikke lade være med at tænke paa, at det er, som om en Jætte havde anbragt Tavlerne paa dette Sted, og her maatte de ikke flyttes bort fra, hvis man da ikke vilde udsætte sig for de værste Følger, i Lighed med de mange Sagn rundt om i Landet om store Sten, som Jætterne havde kastet mod Kirkerne. En 6 til 7 Aar efter, at Mindetavlerne var bleven anbragt paa deres Plads, fik Kirken et nyt Orgel. Flere Grunde talte for, at Orgelet blev anbragt lige over Stolestaderne, fortæller Kirkeforstanderskabets Forhandlingsprotokol af 18. September 1881, men da dette vilde medføre, at 9 Stolestader maatte fjernes, besluttede Kirkeforstanderskabet at lade bygge et nyt Pulpitur paa den nordre Kirkevæg i Lighed med det gamle Pulpitur. Der fremkom ogsaa allerede enkelte Stemmer om, at dette maatte føre til Tavlernes Fjernelse, da de sad i Vejen, hvis Pulpituret skulde lægges i samme Højde som det gamle, hvilket jo maatte anses for det mest naturlige. Og vilde man ikke ofre Tavlerne, saa havde den Udvej jo været tænkelig at sænke Tavlerne saa meget, som Anbringelsen af det nye Pulpitur krævede. Men Nej, Tavlerne maatte der ikke røres ved, derfor lagdes det nye Pulpitur saa højt, at det kom til at ligge oven over Tavlerne! Den arkitektoniske Harmoni lod man haant om! Hvad betød det, at det nye Pulpitur kom til at tage sig underligt skævt ud ved Siden af det gamle, naar man blot kunde undgaa at rore ved de famøse Tavler!

\section{Mindetavlernes Historie.}

I det følgende vil jeg gerne udrede de ejendommelige historiske Begivenheder, der knytter sig til disse Tavler; de har vist 
sig at være endnu mere interessante, end jeg oprindelig antog. Jeg har haft Lejlighed til at studere Kirkeforstanderskabets gamle Forhandlingsprotokoller, som Pastor Wive, Sognets nuværende Præst, beredvilligst har overladt mig til Gennemsyn, ligesom jeg har fundet adskillige interessante Akter paa Landsarkivet i Aabenraa denne Sag vedrørende. Naar man sammenholder alle disse Akter med samtidige Avismeddelelser, særligt fra "Dannevirke«, »Flensborg Avis« og "Fædrelandet«, saa faar man et Billede af hele Affæren, som nok tør kaldes paalideligt. Jeg vilde gerne have sammenholdt det indvundne Materiale med mulige foreliggende Aktstykker i Konsistoriet, eller som det nu. hedder Landeskirchenamt i Kiel for at fjerne mulige Misforstaaelser. For at gøre Billedet tydeligere, vilde det næppe være nødvendigt, men jeg vilde ikke gerne udsætte mig for ikke at have arbejdet saa objektivt som muligt. Aktstykkerne forefandtes, men man mente ikke, at man kunde tillade mig at se dem igennem.

Inden jeg fik Adgang til de førnævnte Aktstykker, havde jeg talt med adskillige om Sagen og faaet en Del mundtlige Overieveringer, som i det store og hele er falden sammen med de faktiske Forhold, som Akterne senere aabenbarede for mig.

Den 2. September 1873 udsendte Hans Majestæt, den tyske Kejser, en Kabinets-Ordre, ifølge hvilken det tillo des at ophænge Mindetavler i Kirkerne for de i Krigen faldne Soldater. Denne Kabinetsordre har nogenlunde omgaaende sat Sindet $i$ Bevægelse hos et Par indvandrede Tyskere i Bolderslev, Fodgendarm Henningsen og Stationsforstander Petersen. (Se Artikel i Dannevirke 17. 2. 1875). For den 23. December s. A. fortæller Kirkeforstanderskabets Forhandlingsprotokol, at Gendarm Henningsen havde indbragt et mundtligt Andragende til Formanden, Pastor Michaelsen om, at der maatte indsættes en Mindetavle i Kirken for Gaardejer H. P. Paulsens Søn fra Smedager. Og Protokollen fortæller videre: "Efter at Formanden havde forelagt Sagen, toge vi undertegnede Kirkeældste følgende Beslutning, at vi efter vor Overbevisning ikke kunde forsvare overfor Menigheden, hvor det vil vække Splid og Strid, uden videre at 
lade en saadan Sten imod Skik og Brug her i Sognet, indsatte i Kirken eller anvise den Plads, og heller ikke kan vi tillade foreløbig, at den indsættes af andre. Da der ingen Lov foreligger, og vi inden for Lovens Grænser har Ret til at bestyre Kirkens Sager, saa er det vort Forlangende, at der indgives til os et skriftligt Andragende, undertegnet af Menighedsmedlemmer, der ønsker det, og vil vi da forelægge Sagen for Menighedsrepræsentanterne, og da i Forening med disse afgive Svar paa det fremsatte Andragende." Protokollen er undertegnet af Jørgen Jørgensen, Jens Petersen, Johan Fr. Andresen og Jes Clausen Strube. Den første og sidstnævnte var fra Bolderslev, de to andre fra Vollerup.

Den 6. Februar 1874 afholdtes det næste Møde i Bjolderup Kirkeforstanderskab, denne Gang sammen med Repræsentanterne. Protokollen fortæller, at der stadig ikke var indsendt noget skriftligt Andragende. Derimod omtaltes en Skrivelse fra Kirkevisitatoriet af 27. Januar 1874, som desværre ikke forefindes mere. Blandt Akterne denne Sag vedrørende, som forefindes i Landsarkivet, er det ældste Udkastet til et Brev fra Kirkevisitatoriet til Konsistoriet, dateret den 13. Juli 1874.

Ved Mødet i Bjolderup den 6. Februar 1874 var ifølge Protokollen alle 4 Kirkeældste og samtlige 12 Menighedsrepræsentanter nærværende. Som eneste Punkt til Forhandling paa Modet var opført Tavlesagen.

Formanden oplæste den foreliggende Skrivelse fra Kirkevisitatoriet og den kejserlige Kundgørelse af 2. Septbr. 1873, og da de 4 Kirkeældste og de 11 Repræsentanter erklærede sig imod Anbringelsen af Tavlen for H. P. Paulsens Søn, udtalte Formanden, at han ikke kunde deltage i Forhandlingerne, hvorefter Kirkeældste Jens Petersen fra Vollerup overtog Formandsposten og ledede Forhandlingerne.

Den ene af Repræesentanterne stemte imod de andre, han er ikke navngivet i Forhandlingsprotokollen, men da den ene bevislig var tysksindet og desuden i Familie med H. P. Paulsen $\mathbf{i}$ Smedager, kan man nok slutte sig til, hvem det har været. Forresten er senere Afgørelser vedtaget udtrykkelig enstemmigt, og 
kun én Gang omtales det, at Bestemmelsen toges af Flertallet, saa han har maaske staaet lidt vaklende.

De vedtog altsaa her at nægte Tilladelsen til Anbringelsen af Mindetavlerne.

1) Fordi det var deres Overbevisning, at de efter Menighedsloven af 16. August 1869, stadfæstet af Hans Majestæt Kejseren, havde Ret til at bestyre Kirkens Anliggender indenfor Lovens Grænser. Men i en Kundgørelse af 8. September 1873 forelaa der efter deres Overbevisning ikke nogen Lov eller Befaling fra Hans Majestæt Kejseren, men kun et Ønske, og det endogsaa kun, hvor Menigheden tillige onskede det.

2) Det var Hans Majestæt Kejserens Ønske, at alle de Faldne fra $1848,1849,1850,1864,1866,1870$ og 1871 skal optages paa Mindetavlen, men her var dette umuligt og urimeligt, da de $i$ de første Krige Faldne ikke kæmpede for den samme Konge og det samme Land, som de $\mathrm{i}$ den sidste Krig Faldne.

3) Menigheden i sin Helhed var imod saadanne Mindetavler i Kirken, og det var her imod al Skik og Brug, saa at selv den Mindetavle, der var ophængt i Kirken for Præsterne, for flere Aar siden er bragt ud af Kirken.

4) Den paatænkte Mindetavle vilde forstyrre Freden og Menighedslivet iblandt dem og stadig være til Forargelse for den store Part af Menigheden.

5) Gaardmand H. P. Paulsens Søn fra Smedager var ingenlunde den eneste, der faldt $i$ den sidste Krig her fra Menigheden, om end han var den rigeste; men foran Metz døde Skræddermester og Husejer Jens Andersen Jensen fra Raved, den 18. Oktober 1870, og hans Hustru og Barn levede endnu i deres Midte. Den 18. Januar 1870 faldt foran Belfort Ungkarl Andreas Andresen fra Bolderslev, der var mere kendt og mere agtet end nogen anden, og hans Brødre og Familie levede endnu i Menigheden. Hvis vi derfor overhovedet kunde tillade nogen Mindestens Indsættelse i Kirken, hvorfor skulde da disse to Krigeres Navne ikke paa Mindestenen. De var ligesaa fuldt hjemmehørende her som Paulsens Søn og visseligen ogsaa ligesaa afholdte og ligesaa tapre. Men deres Familie vilde ikke saare Menigheden ved at onske det, endsige forlange det, og vilde ikke bagefter fore Krig imod den Menighed, til hvilken deres Kære hørte, og hvor deres Minde er agtet, men de vilde nu i Virkeligheden lade dem "Hvile i Fred«.

\section{Protokollen fortsætter:}

"Da det, saaledes som Sagen er bragt frem iblandt os, $i$ et hvert Tilfælde efter vor Overbevisning er imod Hans Majestæts Kejserens (inske, da det strider imod det af os afkrævede og aflagte Løfte, thi det vilde være til stor Skade for Menigheden, da Menighedsrepræsen- 
tanterne alle med Undtagelse af én er enige med os, og da vi mener saavel at have Ret, som vi ogsaa anser det for vor Pligh,

nægter vi herved at anvise Plads $i$ Kirken for en Mindesten for

H. P. Paulsens Søn fra Smedager, og tillader vi heller ikke, at den indsættes af andre, derimod vil vi villig indrømme, at den opsættes paa Kirkegaarden paa Faderens Familiebegravelse, hvor den efter sin Indskrift og sognets Skik og Brug hører hjemme.

Til Slutning spurgte de Kirkeældste Menighedsrepræsentanterne, om de var enige med dem i at føre Sagen for Domstolene, om saa skulde være, og de 11 Repræsentanter erklærede sig derfor. Derefter blev det besluttet, at indsende en Afskrift af Forhandlingsprotokollen til det høje Kgl. Kirkevisitatorium som Svar paa dettes Skrivelse, hvorimod man ikke fandt sig beføjet til at svare Gendarm Henningsen, da han ikke havde henvendt sig til Kirkeforstanderskabet, siden han modtog det forste Svar, og $i$ det hele taget ingensinde henvendt sig til dette $i$ nogen af Menighedens Navn.

Ved Mødets Slutning blev Protokollen oplæst og vedtaget.

Jørgen Jørgensen,

John. Fr. Andresen,
Jens Petersen,

Mathias Th. Knudsen.

Kirkeældste.

Forhandlingens rigtige Overførelse i Forhandlingsprotokollen bevidnet.

\section{Michaelsen p. l.«}

Som det ses, har Kirkeforstanderskabet og Repræsentanterne altsaa været klar over, at de havde Ret $\mathbf{i}$ deres Holdning, og at Lovens Bogstav og Aand helt var paa deres Side. Den eneste Maade til Anbringelsen af den ominøse Tavle kunde ad lovlig Vej nu kun opnaas ved at styrte Kirkeforstanderskabet og Repræsentanterne for paa den Maade at skaffe sig Flertal for sit Ønskes Opnaaelse. Det har de to Ophavsmænd til hele Sagen selvfølgelig ikke formaaet, og saa maatte man prøve paa at naa Maalet ad Omveje. De har nu øjensynlig set sig om efter Hjælpetropper og ogsaa fundet nogle, som kunde slutte sig til dem. Da Simon Johannsen fra Vollerup senere hen fremtræder som Forer for Tavlesagen, kan man vel nok gaa ud fra, at man først har henvendt sig til ham og faaet ham med i Kompagniskabet, men foreløbig nævnes endnu ingen Navne, og desværre forefindes den $i$ det folgende Møde af 13. Maj omtalte skriftlige Henvendelse "fra enkelte Indvaanere her af Menigheden" til Kirkevisitatoriet ikke mere, saa man har stadig intet Holde- 
punkt for, hvem og hvor mange, der har onsket at faa Tavlen ophængt i Kirken.

Mødet den 13. Maj 1874 i Bjolderup Præstegaard overværedes kun af Kirkeforstanderskabet. Formanden oplæste en Skrivelse, som Kirkevisitatoriet havde tilsendt Kirkeforstanderskabet fra enkelte Indvaanere i Bjolderup om en Mindetavles Indsættelse i Bjolderup Kirke.

Formanden forespurgte, om de Kirkeældste ikke kunde tillade, at den indsattes i Kirken, hvortil de svarede, at det kunde de ikke, da det overalt vilde vække Anstød og Forargelse. Dernæst forespurgte Formanden, om de ikke kunde tillade det, hvis alle de tre Faldnes Navne sattes paa Stenen, og denne da sattes ind i Kirken. Dertil svarede de, at dette Spørgsmaal ikke forelaa, men at de iøvrigt ogsaa derpaa vilde svare benægtende. Da Formanden herefter ikke vidste nogen Udvej til Udjævning af Sagen. blev de Kirkeældste enige om at afgive folgende Erklæring:

„Som Gensvar paa den os af enkelte Indvaanere i Bjolderup Sogn underskrevne tilsendte Skrivelse af 28. April d. A., der aldeles ikke indeholder noget nyt, har vi ikke nogen anden Erklæring at afgive, end hvad vi tidligere i Forening med Menighedsrepræsentanterne i Beslutningen af 6. Februar d. A. har svaret, og vi tillader os derfor at henvise dertil. Skulde det haje Kgl. Kirkevisitatorium iøvrigt ønske, at vi skal bevise, at Grundene i den indgivne Skrivelse er løse og usande, saa er vi villige dertil.

Vi maa derfor ifølge vort Løfte og Haandslag ifølge den Lov, der er givet os at følge, og den Menighed, som vi repræsenterer, afgive den tidligere Erklæring, at vi aldrig kan give vort Minde til, at den omtalte Sten indsættes i Kirken, men derimod, som alt sagt, tillader vi gerne, at den hensættes paa Faderens Familiebegravelse paa Kirkegaarden, paa hvilken alle Mindesmærker for afdøde her efter Sognets Skik og Brug oprejses."

Den 17. Maj 1874 afholdt Kirkeforstanderskabet i Bjolderup Præstegaard et nyt Møde. Her nævnes for første Gang Simon Johannsen fra Vollerup, idet man paa dette Mrde skulde tage Stilling til en Skrivelse fra ham tilligemed en Skrivelse fra Kirkevisitatoriet. Simon Johannsens Skrivelse er altsaa gaaet gennem Kirkevisitatoriet til Kirkeforstanderskabet. Den forefindes desværre ikke mere. Da der foreligger en senere Skri- 
velse fra S. Johannsen, vil man af dennes Stil, som følger senere, kunne forstaa, at man her er gaaet Glip af et sikkert interessant Brev. Kirkevisitatoriets Skrivelse gik ifølge Forhandlingsprotokollen ud paa, at Kirkeforstanderskabet enten inden en Frist af 14 Dage skulde indgive Recurs til en højere Autoritet eller ogsaa maatte finde sig $i$ den af Kirkevisitatoriet afsagte Dom. Imidlertid havde en stor Del af Menigheden sat sig i Bevægelse, idet man havde underskrevet en Erklæring om, at. man sluttede sig til Kirkeforstanderskabets Fremgangsmaade. Denne Erklæring fremlagde de Kirkeældste nu, og da man "ikke kendte nogen Autoritet, til hvilken de skulde henvende sig«, blev man enige om at indsende følgende Erklæring til Kirkevisitatoriet:

"Da vi undertegnede Kirkeældste er af den Overbevisning, at vi ifølge Menighedsloven har Ret til paa Menighedens Vegne at raade over Kirken, og da det efter medfølgende Erklæring fra den store Part af Menigheden er klart, at det ikke er fra landsfjentlige Menighedsmedlemmer, der er Sagen imod, men saa at sige hele Menigheden er imod, at en saadan Sten indsættes i Kirken, saa er vi nødsaget til at fastholde vor Nægtelse, og idet vi ikke kender nogen Autoritet, til hvilken vi skal henvende os, da Kirkens Selvstyrelse med Hensyn til Bygningerne er anerkendt ved Lov, saa tillader vi os at indsende vedlagte Erklæring fra omtrent hele Menigheden til det høje Kgl. Kirkevisitatorium, og idet vi haaber, at højstsamme deraf vil faa en anden Anskuelse af Sagen og indse, at det ikke fra vor Side er nogen personlig Sag, men omtrent hele Menighedens Sag, vedføjer vi den Bøn, da en saadan Stens Indsættelse hverken er til Menighedens Opbyggelse eller Guds Ære, at det høje Kgl. Kirkevisitatorium da vil billige og godkende vor Udtalelse.«

Som det ses ovenfor, har Kirkeforstanderskabet altsaa ikke vidst, til hvilken Myndighed det skulde henvende sig. Kirkevisitatoriet har da i en Skrivelse af 20. Juni, som desværre heller ikke forefindes, givet Kirkeforstanderskabet de nødvendige Oplysninger. Denne Skrivelse har givet Anledning til et Møde den 29. Juli 1874 i Bjolderup Præstegaard. Skrivelsen blev oplæst og angaaende den deri fremsatte Ordre til enten at finde sig i Mindetavlernes Indsættelse eller ogsaa inden 14 Dage at indgive Recurs til Konsistoriet i Kiel, vedtog man følgende Erklæring: 
"Da, som vi før har udtalt, det er vor fulde Overbevisning, at Kirkemenigheden gennem sin egen Repræsentation har Lov til selv at bestyre sine Sager (cfr. Menighedslov af 16. August 1869 \& 1.), og da her ikke foreligger nogen Lov, der paabyder en saadan Stens Indsættelse i alle Kirker, saa kan vi undertegnede Kirkeældste og Bjolderups Menighedsrepræsentation ikke finde os foranlediget til i en Sag, der blot efter vor Overbevisning er en Menighedssag, hvor den almindelige Stemmeret gælder, at henvende os til nogen højere Autoritet.

Som det høje Kgl. Kirkevisitatorium ved, saa har den tit omtalte Sag kun faaet 1 Stemme af 16 i Repræsentationen og heller ikke flere i Menigheden, og da det nu ogsaa efter Menighedens Erklæring vil være det høje Kgl. Kirkevisitatorium bekendt, at Sagen ikke er nogen politisk Sag, ligesom ogsaa alle, hvis Sønner er Soldater eller trukne til Soldater, er imod en saadan Stens Indsættelse i Kirken af de tidligere anførte Grunde, saa holder vi paa vor og Menighedens Ret og den almindelige Stemmeret ogsaa i denne Sag, indtil der vises os en Lov, der berøver os og Menigheden denne Ret, eller en Lov, der paabyder en saadan Stens Indsættelse i alle Kirker, hvor det i Forvejen ikke er Skik og Brug, og ikke i Bjolderup Kirke alene.

Er det høje Kgl. Kirkevisitatorium af en anden Mening og ikke tilfreds med det Resultat, som Repræsentationens og Menighedens Afstemning har frembragt, endog vi ikke kan skønne, hvorfor en saa forsvindende Minoritet skulde være raadende i en Menighedssag, saa har vi intet imod, at Højstsamme klager over os og indanker Sagen videre, men vi maa fastholde vor Nægtelse, saa længe det er vor Overbevisning, at vi staar paa Lovens Grund, og saa længe som vi er bunden ved det os afkrævede og højtideligt aflagte Løfte, da vi i denne Sag ikke kan anerkende det høje Kgl. Kirkevisitatorium som nogen lovgivende Magt.«

Imidlertid var de 14 Dages Frist ved at udløbe, og man traadte nu sammen til et nyt Møde den 10. Juni 1874.

Formanden spurgte paa dette Møde, hvilket Resultat man var kommen til med Hensyn til den Frist, Kirkevisitatoriet havde stillet. De Kirkeældste afgav derpaa den Erklæring, at de efter en gentagen moden Overvejelse maatte fastholde deres Overbevisning, at Kirkeforstanderskabet ifølge Menighedslovens $\S 1$ var beføjet til indenfor Lovens Grænser at varetage Kir. kens Anliggender, og da Hans Majestat Kejseren havde lagt denne Myndighed $\mathbf{i}$ deres Embede, saa saa de sig ikke foranledigede til at indgive nogen Recurs, men at fastholde deres tidligere Beslutning hverken at lade Stenen indsætte og heller ikke at tillade, at den indsættes af andre. 
Her skete altsaa nu den første Fejl. Kirkeforstanderskabet forsømte at gaa Besværingsvejen - eller som man her kaldte den, Recurs-Vejen - og derved lykkedes det den snilde Provst Gøttig at overrumple Kirkeforstanderskabet. Men Præsten synes nu at have stillet sig absolut neutral, han maa have set, at den Vej, som Loven paabød, og til hvilken Kirkevisitatoriet havde henvist dem, var den eneste, der nu kunde føre dem ud af et Uføre, som oprindelig et Par tilflyttede tyske Embedsmænd havde været Aarsag til. Iøvrigt er det nu ganske interessant at lægge Mærke til, at fra nu af træder disse to helt tilbage i den mørke Ubemærkethed, fra nu af er det Simon Johannsen, der staar som Fører, og med hans Indflydelse lykkes det øjensynligt at faa flere til at slutte sig til Kravet. Der omtales i en nu følgende Beretning fra Kirkevisitatoriet til Konsistoriet en Begæring om Anbringelsen af Tavlen, som er undertegnet af 30 Menighedsmedlemmer, deraf 22 Gaardejere. Da de 22 Gaardejere er fremhævet, tør man vel gaa ud fra, at de 8 er tilfæ̇ldige Tjenestefolk, som ikke har kunnet modstaa deres Husbonds Paavirkning. Og naar man betænker, at Sognet paa den Tid har haft en ca. 1500 til 1600 Indbyggere, er Antallet af de 30 jo ikke sæligt imponerende. Og man kan være vis paa, at flere har ikke kunnet skaffes.

\section{Sagen fremlægges for Konsistoriet.}

Den 13. Juli 1874 har Kirkevisitatoriet indsendt en øjensynlig første Beretning om Tavlesagen til Konsistoriet. Efter Fremstillingen af Sagen siges heri, at da Kirkeforstanderskabet blandt andet havde begrundet sin Nægtelse med, at Paulsens Søn ikke var den eneste fra Sognet, som var falden i den franske Krig og havde navngivet to flere, havde Kirkevisitatoriet anbefalet Petenterne at tage disse to med paa Tavlen eller at rejse tre ligelydende Tavler for de Faldne. Men ogsaa dette Forslag, som Kirkevisitatoriet havde stillet, nægtede Kirkeforstanderskabet at gaa ind paa. Petenterne havde saa indlagt Recurs hos Kirkevisitatoriet, undertegnet af $" 30$ Medlemmer 
fra Sognet, deriblandt 22 Gaardejere«. - Dokumentet med de 30 Underskrifter forefindes desværre heller ikke mere. - Kirkeforstanderskabet havde imidlertid stadig fastholdt sin Nægtelse, og samtidig havde det indsendt en Erklæring, undertegnet af en stor Del af Sognets Beboere, som stillede sig helt paa Kirkeforstanderskabets Side. Kirkevisitatoriet havde ophævet Kirkeforstanderskabets Forbud og givet Petenterne Tilladelse til Anbringelsen af Tavlerne, efter at Kirkeforstanderskabet havde forsømt at indsende Recurs til Konsistoriet. Pladsen anvistes paa Væggen lige over for Indgangen.

Kirkevisitatoriet slaar allerede $i$ denne Indberetning paa den Mulighed, om ikke en Opløsning af Kirkeforstanderskabet vilde være anbragt, men bemærker rigtignok samtidigt, at en saadan Fremgangsmaade næppe vilde skaffe et mere medgørligt Kirkeforstanderskab. Der følger saa en Sætning, som man ikke kan tyde helt nøje, men af Ordene, som det har været muligt at tyde, forstaar man, at Kirkevisitatoriet foreslaar at lade Tavlerne anbringe med Magt $i$ Kirken og saa lade Retten træffe en Afgørelse senere. Kirkevisitatoriet har altsaa den Gang allerede regnet med, at Retten vilde støtte Magthaverne i Kampen mod det svagere Kirkeforstanderskab. - For Præstens Vedkommende androg Kirkevisitatoriet paa, at der maatte tildeles ham en alvorlig Revselse - eine ernste Rüge - , d a $\mathbf{~ h ~ a ~} \mathbf{n}$ skal have udtalt sig om, at han stod paa Kirkeforstanderskabets $S i d e$, men nu øjensynligt søger at holde sig passiv.

\section{Tavlerne indsættes i Kirken og fjernes igen.}

I Akterne i Landsarkivet i Aabenraa forefandtes et Dokument, som er betitlet "Aktum 26. Oktbr. 1874 fra Aabenraa Provsti«. Dette Dokument fortæller følgende:

Stenhugger Gebhardt madte frem med følgende Melding: Han var Dags Morgen kørt til Bjolderup med en Mursvend for at indsætte de for Kirken bestemte Mindetavler. Efter at Pastor Michaelsen havde aabnet Kirken for ham paa hans Anmeldelse hos Præsten, og efter at de havde aflæsset deres Vogn, kom Degn Tøgesen og overrakte Geb- 
hardt vedføjede Brev fra de 4 Kirkeældste, dateret 17. 10. 1874, i hvilket man forbød ham Indmuringen af Tavlerne i Kirken. Præsten havde fjernet sig, hvorimod der havde samlet sig en Del tysksindede Sognemedlemmer ved Kirken. Medens man gik tilbage til Kroen for at forhandle om Sagen, kom de to Kirkeældste M. Th. Knudsen og Jørgen Jørgensen, som mundtlig gentog det allerede skriftlig afgivne Forbud og afkrævede Gebhardt Kirkenøglen, Gebhardt veg for Overmagten, idet han dog henviste til den Fare, som de løb, samt paa de Omkostninger, som vilde fremkomme. Han tilbageleverede Nøglen, lod det tilkørte Materiale og Haandværkstøj føre i Sikkerhed hos Baneforvalteren i Bolderslev og kørte tilbage til Aabenraa. Idet han først henviser til Datoen af 17. ds., beder Gebhardt om Hjælp mod de Kirkeældste samt om Erstatning af Omkostningerne.

Dokumentet er undertegnet af Gøttig.

Det oven omtalte Brev fra de Kirkeældste til Gebhardt har følgende Ordlyd:

"Da det er kommet til vor Kundskab, at De skulde være antaget til at indsætte en eller flere Mindetavler i Bjolderup Kirke, gør vi undertegnede Kirkeældste for Bjolderup Menighed Dem herved opmærksom paa, at vi hermed forbyder Dem at foretage noget som helst Arbejde i nævnte Kirke uden vor Tilladelse ifølge den Myndighed, som Menighedslovens $\S 2$ hjemler os."

Ifølge Landraadens Indberetning til Regeringen i Slesvig af 22. 12. udviklede Sagen sig da saaledes:

Gebhardt vendte altsaa hjem med uforrettet Sag og bad om Hjælp hos Kirkevisitatoriet mod de oprørske Bønder. Kirkevisitatoriet - bestaaende af Landraaden og Provsten - anmodede Landraaden om Beskyttelse for Haandværkerne under deres Arbejde med Indmuringen af Tavlerne mod Bøndernes Indgriben. Landraaden beordrer en Gendarm til at følge med en Murer hen til Bjolderup Kirke, og denne staar nu Vagt her i Dagene fra den 17. til den 19. December, saa Indmuringen af Tavlerne kan ske uforstyrret. Den 19. December henimod Aften er Arbejdet fuldfort, og Mureren samt Gendarmen forsvinder fra Skuepladsen.

Samme Eftermiddag afholder Kirkeforstanderskabet Møde i Præstegaarden og bestemmer, at de indmurede Tavler straks skal fjernes, da de efter dettes Overbevisning er indmurede med Urette. 
Den paagældende Forhandlingsprotokol har følgende Ordlyd:

"Sket i Bjolderup den 19. Decbr. 1874.

Efter at de Kirkeældste havde forlangt et Møde afholdt i Dag Kl. 1, mødte de alle. De foreslog til Afgørelse, at den Mindesten, som Simon Johannsen fra Vollerup $m$. fl. havde ladet indsætte i Kirken, skulde udtages og Sag anlægges imod ham. Ved Afstemningen stemte alle de Kirkeældste derfor, Formanden afholdt sig fra at stemme. Dernæst foreslog de, at der udstilledes en lovformelig skriftlig Erklæring, hvorved de Kirkeældste Jens Petersen og Jørgen Jørgensen bemyndigedes til at antage en Sagfører for at føre Sagen igennem, og at derimod de to andre Kirkeældste bemyndigedes til at lade Stenen udtage, ogsaa denne Sag vedtoges af alle de Kirkeældste, medens Formanden afholdt sig fra at stemme.

Kirkevisitatoriet sparer ikke paa Krudtet ved Indberetningen til Konsistoriet om denne Skændselsdaad. Efter vor Anskuelse, hedder det, kan det ikke være tvivlsomt, at denne Handling falder ind under Straffelovens \$ 304. Denne de Kirkeældstes Handling er afskyelig (entsetzlich) og lovstridig og foretaget bevidst mod deres foresatte Myndigheds lovlige Anordning.

Men iøvrigt forbeholder Kirkevisitatoriet sig med Hensyn til de kirkelige Myndigheders Fremfærd mod de Kirkeældste en senere Indberetning, som vil blive indsendt, naar der er indhentet en nærmere Forklaring fra Pastor Michaelsen, og efter at de Kirkeældste er afhørte, hvilket er fastsat til førstkommende Lørdag.

Tavlernes Nedtagelse har sat mange Penne i Bevægelse, men ingen har dog flydt med mere Galde end Gaardejer Simon Johannsens fra Vollerup, da han 21. December sendte Kirkevisitatoriet en Meddelelse om det skete. Brevet lyder i Oversættelse:

"Herved undlader jeg ikke at lade det kgl. Kirkevisitatorium i Aabenraa tilkomme en ubehagelig Meddelelse (ja, maaske ved De det allerede), at de Kirkeældste om Aftenen eller Natten, endnu samme Aften, som Tavlerne var indmuret, har ladet dem nedtage igen. En af de Kirkeældste, nemlig Johan Fr. Andresen, kom i Gaar Eftermiddags hen til mig og meldte, at de Kirkeældste havde taget Mindetavlerne ned, og at de var stillet hen i Taarnet i Kirken, men frem- 
kom samtidig med den naive Bemærkning, at der vilde man ikke have Tavlerne staaende længe, vi maatte sørge for, at de kom ud af Kirken. Men det gør vi da sandelig ikke. De har sidst haft Tavlerne i Hænde, saa lader vi Kirkeforstanderskabet ganske roligt sætte Tavlerne, hvor de vil. Ja, Sagen har nu efter min Formening naaet Højdepunktet, over hvilken en Afgørelse ikke kan ubeblive længe. Nu maa det snart vise sig, hvem der har Magten (wer die Gewalt hat), enten den høje Øvrighed eller de Kirkeældste. Imidlertid overlader vi Sagen i Deres Hænder, men vi beder tillige, at de vil gribe Sagen an med Alvor og saa snart som muligt for at redde deres og vor Ere. Samtidig beder vi om behagelig Efterretning, paa hvilket Stadium Sagen befinder sig.

Høfligst og Erbødigst

S. Johannsen.

Det, der er det mest paafaldende i denne Skrivelse ,er Simon Johannsens ejendommelige Indstilling over for den Sag, det her drejer sig om. Han dokumenterer her, at for ham gælder det ikke om at sætte et Minde for et Par Soldater, der er faldet $i$ Frankrig, men for ham er det en tysk Sport. Det synes for Resten ufatteligt, at de Paarørende til de to senere medtagne ikke har nedlagt en bestemt Indsigelse mod Tyskernes »Trang til at hædre« deres Kæres Minde ved at paatvinge Menigheden en Mindetavle, der forkyndte, at de var faldne for "Konge og $\mathrm{F}$ dreland", hvilket for Andresens Vedkommende $i$ alt Fald var en bevidst Usandhed, formodentlig ogsaa for Skræddermester Jens Jensens, efter de Kirkeældstes Udtalelse om dem begge to.

Akterne udviser ikke noget Svar paa denne meget paatrængende og strenge Forespørgsel. Man har altsaa maaske lagt Skrivelsen ubesvaret til Akterne og derved overgivet til Efterverdenen et af de bedste Beviser for hele Sagens Hulhed og Forløjethed. Da der ikke forefindes flere Breve fra S. Johannsen i Akterne, kunde det jo ogsaa tyde paa, at selv Gøttig ikke har onsket at korrespondere med den Mand, som man dog har kunnet bruge til at fremme sine Maal.

Den 5. Januar 1875 har Kirkevisitatoriet saa samlet mere Materiale til en ny Indberetning til Konsistoriet. Ved Siden af det forfærdelige, som de fire Kirkeældste altsaa havde udøvet ved Fjernelsen af Tavlerne, understreges stærkt $i$ den nye Indberetning, at Kirkeforstanderskabet havde forsømt at indsende 
Recurs til Konsistoriet, til Trods for wat vi baade mundtligt og skriftligt har henvist Kirkeforstanderskabet til denne eneste tilladte Vej«. De afhørte Kirkeældste paaberaabte sig for deres Fremgangsmaade Menighedslovens $\S 1$, idet de mente, at de efter denne har uindskrænket Raadighed i Forvaltningen af Sogneanliggender, og betragtede deres Beslutning som uigenkaldelig og som uophævelig af nogen Myndighed, skønt Kirkevisitatoriet i Anledning af en Kirkevisitation havde foreholdt dem det meningsløse (Unsinnige) i deres Paastand.

"Det vil altsaa være paatrængende nødvendigt, for at sætte en Grænse for slige Overgreb, at statuere et alvorligt Eksempel, og vi andrager derfor paa, at Kirkeforstanderskabet i Henhold til $\$ \$ 29$ og 21 i Menighedsloven opløses for grov Pligtstridighed og desuden paa Frakendelsen af den aktive og passive Valgret."

"Hvad angaar Formanden, Herr Pastor Michaelsens Adfærd, saa synes hans Afholdelse fra at stemme samt den Omstændighed, at han ikke opfyldte den Forpligtelse, som paahviler ham efter \$ 34, ligeledes at maatte dadles, og vi henstiller, at der $i$ den Anledning paa en eller anden Maade (irgend wie) maa gaaes disciplinært frem imod ham.

Endelig tillader vi os endnu at andrage paa, at der maa paalægges Kirkeforstanderskabet at anbringe Mindetavlerne, som de midlertidig har taget i Forvaring, paa det Sted, hvorfra de or fjernede, og paa samme Maade, og at overlade til samme at inddrage Omkostningerne, som fremkommer herved, igen fra de Skyldige.*

Om Nedtagelsen af Tavlerne havde "Dannevirke" den 31.12. 1874 følgende Artikel:

"I længere Tid har nogle Tysksindede i Bjolderup Sogn gjort sig Ulejlighed for at faa en Mindetavle over en i 1870 falden Soldat der fra Sognet anbragt i Sognets Kirke, men Sagen strandede paa Kirkeforstanderskabets Modstand, som ikke onskede Politik bragt ind i Kirken og dernæst gjorde opmærksom paa, at der var falden tre Soldater fra Sognet i 1870, om den ene end var en rig Mands Søn, saa laa der ingen Grund heri til at trække ham frem paa de andres Bekostning. Kirkeforstanderskabet fik den ene Befaling efter den anden fra Kirkevisitatoriet, men hint holdt paa sin lovlige Ret til at tage Bestemmelse om Kirkens Udstyrelse og nægtede bestemt Tavlens Indsættelse. En skønne Dag i næstforrige Uge mødte imidlertid en Stenhugger fra Aabenraa, i Ledtog med en Gendarm, og efter at have tiltrodset sig Nøglen hos Degnen, gav han sig uden Kirkeforstanderskabets Vidende og Vilje, stadig beskyttet af Gendarmen, til at indmure tre Mindetavler i Kirken. Saa megen Imødekommen skulde der altsaa dog vises, at man nu havde faaet alle tre Faldne med. Men Kirkeforstanderskabet 
har saa lidt paaskønnet denne Imødekommen, at det straks Lørdag Aften den 19. Decbr. nedtog alle Tavlerne og derefter har anlagt Sag imod Stenhuggeren for Krænkelse af Sognets uforstyrrede Besiddelsesret til Kirkebygningen. Tyskerne er naturligvis rasende, og Autoriteterne synes ogsaa at være blevet fraperet over Kirkeforstanderskabets selvstændige Holdning. Dettes Medlemmer maatte i Mandags $\mathrm{I}$ Forhør hos Politimesteren, Herredsfoged Jensen, som nok skal have truet med Statsadvokaten. Heller ikke dette har gjort noget Indtryk paa Kirkeforstanderskabet i Bjolderup, der ved, at de har Lovens Aand og Bogstav paa sin Side, men det skal nu rigtignok prøves, om "Selvbestyrelsen" i Nordslesvig, naar den træder hindrende i Vejen for Udførelsen af politiske Planer, er andet end et dødt Bogstav, thi det har desværre altfor ofte vist sig at være Tilfældet.«

\section{Regeringen i Slesvig griber ind.}

$\mathrm{Nu}$ melder Regeringen i Slesvig sig og kræver Indberetning, idet den henviser til "Dannevirke«s forfalskede (entstellten) Referater, "som ogsaa har fundet Vej til større Aviser uden for Provinsen", altsaa har begyndt at volde ubehagelig Opsigt. En ny Indberetning maa indsendes, og som Nervøsiteten stiger, sendes nye Momenter i Marken. I Indberetningen til Konsistoriet var det et Antal Menighedsmedlemmer, til Regeringen bliver det til ansete Mienighedsmedlemmer. Regeringen underrettes om, at Kirkevisitatoriet straks har overdraget Undersøgelsen til Herredsfogden, og senere overgivet den til Statsadvokaten. Man har andraget hos Konsistoriet paa at opløse Kirkeforstanderskabet paa Grund af dets grove Pligtstridighed samt at fratage de Kirkeældste aktiv og passiv Valgret.

Saaledes ligger Sagen for Tiden. Desuden har Kirkeforstanderskabet, slutter Indberetningen, indbragt en Civilklage ved Amtsretten imod Stenhugger Gebhardt for Indgreb i Ejendomsretten. Der er af Retten ansat Termin til den 15. d. M.

Dagen efter fulgte en lignende Indberetning til Regeringspræsident Bitter i Slesvig fra Landraaden, ogsaa han fik at vide, at Kirkeforstanderskabet havde anlagt Sag mod Gebhardt.

Man har Indtryk af, at Efterretningen om Kirkeforstanderskabets Sag mod Gebhardt volder større Forfærdelse i Slesvig end selve "Udaaden med den voldelige Fjernelse af Tavlerne«, 
som efterfølgende Skrivelse fra Regeringen til Kirkevisitatoriet $\mathbf{i}$ høj Grad bærer Vidnesbyrd om, den gengives her i Oversættelse:

"Af Deres behagelige Indberetning af 7. ds., indgaaet her den 13. ds., vedrørende Mindetavlerne i Bjolderup Kirke, ser vi, at Kirkeforstanderskabet har indgivet en Klage mod Stenhugger Gebhardt for Forstyrrelse af Ejendomsretten, og at Amtsretten har ansat Termin í denne Sag til den 15. cr.

Da det efter \$ 51 i Menighedsloven af 16. August 1869 til Processer, som Kirkeforstanderskabet vil fore, kræves, at dette ikke blot skal have Tilslutning fra Menighedsrepræsentanterne, men ogsaa den højere Tilladelse er nødvendig, naar det ikke blot er likvide Skyldfordringer, som skal indklages. Men da den højere Tilladelse, det vil sige Autorisation fra det kgl. Kirkevisitatorium, i den foreliggende Processag heller ikke er givet, det tør vi vel nok antage uden videre, saa burde efter vor Mening en Klage for Ejendomsforstyrrelse allerede af den Grund ikke være indledet af Kirkeforstanderskabet, da det manglede den nødvendige Proceslegitimation.

Skulde imod al Forventning denne Mangel og den Omstændighed, at Gebhardt ikke paa egne Vegne, men efter Bemyndigelse fra det kgl. Kirkevisitatorium og til Gennemførelse af en Anordning fra en gejstlig Myndighed har indsat Mindetavlerne i Væeggen i Bjolderup Kirke, ikke medføre Tilbagevisningen af sagen om Indgreb i Ejendomsretten, men tværtimod Gebhardt skulde blive dømt, saa beder vi det $\mathrm{kgl}$. Kirkevisitatorium o $\mathrm{mg}$ a a e $\mathrm{nde}$ at ville indsende Dommen sammen med Klageskriftet i Afskrift til os; for at vi rettidig kan vedtage en Beslutning om eventuel Hævdelse af Kompetence-Konflikten.

Vi vilde $i$ det hele have onsket, at vi havde faaet Meddelelse om denne Ejendomsforstyrrelsesklage rettidig før den 15 . cr. med Indsendelsen af Klageskriftet, for at vi endnu før denne Termin havde kunnet vedtage en Beslutning om Hævdelse af Kompetencekonflikten.

Hvis Kirkeforstanderskabet afvises med sin Klage, saa venter vi ogsaa herom deres Indberetning. Ikke mindre vil De sende os Meddelelse til sin Tid om den Beslutning, som det kgl. Konsistorium og Statsadvokaten tager i denne Sag."

Regeringens Nervøsitet træder ubestridelig stærkt frem her, Kirkeforstanderskabet kan jo slet ikke anlægge nogen Sag uden det kgl. Kirkevisitatoriums Autorisation, og at denne ikke kan foreligge til en saadan Sag, det maa man vel nok anse for givet! Altsaa en alvorlig Næse til Kirkevisitatoriet, som her ikke havde været agtpaagivende! Men nu er Skaden sket, og Regeringen ser allerede de mest truende Muligheder i Horisonten. Man holder det for muligt, at Gebhardt skulde blive dømt, skønt 
han ikke havde foretaget Indmuringen paa eget Initiativ men efter Bemyndigelse af Kirkevisitatoriet for at udføre den gejstlige Myndigheds Anordning! Og saa er der endelig en Næse til Kirkevisitatoriet, fordi man ikke havde sendt Indberetningen saa betids, at Regeringen kunde have interveneret, før Terminen den 15. ds. var fastsat. Indberetningen var skrevet allerede den 7. men forst indgaaet i Slesvig den 13. ds.!

Der er ingen Tvivl om, at hele Historien i dette Øjeblik er $i$ den største Fare, den kan uventet tage en farlig Vending. Hvorfor ellers Nervøsiteten? Men Angstelsen viser sig heldigvis for Myndighederne at have været ganske overflødig. Amtsretten var Situationen voksen. De Kirkeældste afvistes med deres Klage paa Grund af, at de savnede Kirkevisitatoriets Autorisation!

\section{Konsistoriets Afgørelse.}

Den 26. Januar 1875 afsendte Konsistoriet sit Svar paa Kirkevisitatoriets Skrivelser af 30. f. M. og 5. ds., der i det store og hele imødekommer Kirkevisitatoriets Andragende. De fire Kirkeældste afskediges for grov Pligtstridighed, og der anordnes nyt Valg af Kirkeældste. Valget skal finde Sted under Kirkevisitatoriets Ledelse; derimod har man ikke fundet tilstrækkeligt Grundlag til en disciplinær Undersøgelse mod Pastor Michaelsen. Der vedføjes et Brev til Præsten, som Kirkevisitatoriet skal sende videre. Endelig udbeder Konsistoriet sig, at Kirkevisitatoriet snarest vil indsende Indberetning om det foretagne ny Valg og om Fremgangsmaaden ved samme.

Konsistoriet meddeler Kirkevisitatoriet, at man har sendt Akterne til Statsadvokaten i Flensborg, for at der kan tages endelig Beslutning om strafferetslig Indskriden mod de hidtilværende Kirkeældste. Dog med Hensyn til yderligere Forholdsregler, som det kgl. Kirkevisitatorium har andraget om, for at faa Mindetavlerne indsat igen, vil Konsistoriet komme tilbage hertil, naar den indkrævede Indberetning om Nyvalget foreligger. 
Allerede Dagen efter, den 27. Januar, sendtes Konsistoriets Afgørelse videre til Kirkeforstanderskabet i Bjolderup. Man har vel nok været noget mellemfornøjet med at maatte meddele de Kirkeældste, at deres Valgret og Valgbarhed, hvis Fratagelse Kirkevisitatoriet havde andraget paa, kun skulde fratages dem for det tilstundende Valg, samt at den krævede disciplinære Undersøgelse mod Præsten heller ikke toges til Følge. Men Brevet til Pastor Michaelsen fra Konsistoriet har dog formodentlig været af en saadan Beskaffenhed, at det har præget hans senere Indstilling overfor Sagen, der for Fremtiden undergik en kendelig Forandring. Iøvrigt skal denne Skrivelse fra Kirkevisitatoriet her gengives i sin Helhed i Oversættelse:

„Det Kgl. evg. Luth. Konsistorium har besluttet, efter at det af vor Indberetning af 5 . ds. har set, at Mindetavlerne, som var indsat med det Kgl. Kirkevisitatoriums Tilladelse og paa dettes Anordning for de Medlemmer fra Bjolderup Sogn, som var blevet i Krigen, men samme Dag med Vold var bleven fjernet fra Kirkens Væg, hvor de var indsat, paa Foranledning af Kirkeforstanderskabet dersteds, idet de har udført en Beslutning, som Kirkeforstanderskabet har vedtaget den 19. Decbr. f. A. under Formandens Afholdelse fra at stemme, men ellers enstemmig,

1) at ophæve Bjolderup Sogns Kirkeforstanderskab i Henhold til kirkelig Menighedslov af 16 . August $1869 \& 29$ paa Grund af grov Pligtstridighed, udvist ved at tage den ovenomtalte Beslutning og straks efter at udføre den. Endvidere skal de valgte Medlemmer $i$ det opløste Kirkeforstanderskab fratages den kirkelige Valgret og samtidig hermed Valgbarhed ved det forestaaende Nyvalg.

Idet vi meddeler ovenstaaende efter Bemyndigelse fra det Kgl. evgl. Luth. Konsistorium til Kirkeforstanderskabet samt dets valgte Medlemmer, underretter vi samtidig sidstnævnte om, at de i Henhold til de foreliggende Forhold maa afholde sig fra enhver Funktion som Kirkeældste, som dem ikke mere vedkommende.

Med Ledelsen af Valget af det nye Kirkeforstanderskab har det Kgl. evg. Luth. Konsistorium bemyndiget undertegnede Kirkevisitatorium.

2) Til Herr Pastor Michaelsen, Velærværdighed, i Bjolderup.

Deres Velærværdighed oversender vi i Bilagene

1) En Skrivelse (Eröffnungsschreiben) fra det Kgl. evg. Luth. Konsistorium til Dem selv.

2) En Skrivelse til Kirkeforstanderskabet med Opfordring til straks at gøre dette bekendt med Indholdet,

3) En Bekendtgørelse, som skal oplæses fra Prædikestolen førstkommende Søndag. 
Samtidig beder vi Deres Velærværdighed om at sammenkalde Menighedsrepræsentanterne til Torsdag den 4. Febr. Eftermiddag Kl. 3 paa Præstegaarden for at foretage Valg af 4 Kirkeældste.

3) Bekendtgørelse for Bjolderup Menighed:

Efter at det var kommet til det Kgl. evg. Luth. Konsistoriums Kundskab, at den med Kirkevisitatoriets Samtykke indsatte Mindetavle for de i Krigen døde Medlemmer af Bjolderup Menighed, af de Kirkeældste i Udførelse af en Beslutning, som Bjolderup Kirkeforstanderskab har fattet den 19. f. M. med alle Stemmer med Undtagelse af Formandens, der afholdt sig fra at stemme, endnu samme Dag med Vold er nedtagne af Kirkens Væg, i hvilken de var indmurede, har Konsistoriet under 26. d. M. besluttet paa Grund af den med næunte Beslutning og dens Udførelse udviste grove Pligtstridighed i Henhold til $\$ 29$ i Menighedsloven af 16. August 1869 at opløse Kirkeforstanderskabet samt at unddrage de valgte Medlemmer af det opløste Kirkeforstanderskab den kirkelige Valgret og samtidig Valgbarheden for det tilstundende Valg.

Idet vi bringer foranstaaende til Menighedens Kundskab, tilføjer vi, at vi af det høje Kgl. evg. Luth. Konsistorium er bemyndiget til at lede Valget af 4 Kirkeældste til Dannelse af et nyt Kirkeforstanderskab, og at Udfaldet af Valget vil paa den foreskrevne Maade i sin Tid blive forkyndt for Menigheden.

Det Kgl. Kirkevisitatorium.

W. C. von Levetzau. Göttig."

Dermed var altsaa de 4 Kirkeældste afsatte. At dette har vakt mere end almindelig Opsigt, er givet, og Avisudtalelser i denne Anledning belyser bedst Mentaliteten baade i den snævre Omegn og i fjernere Egne. "Dannevirke» skriver herom den 17. Febr. 1875: "Som allerede meddelt, har Konsistoriet i Kiel afsat de Kirkeældste i Bjolderup Sogn og ladet foranstalte nyt Valg, hvilket dog kun har haft til Følge, at Mænd, der deler samme Anskuelse om denne Sag, som de afsatte, er valgte. Dette er altsaa et afgørende Bevis for, at Menighedens store Flertal billiger den Holdning, som dens Kirkeældste har indtaget $\mathbf{i}$ denne Sag. Konsistoriet maa imidlertid have en anden Mening, siden det har fundet sig beføjet til at afsætte dem. I Loven af 16. Aug. 1869 om Menighedsordningen hedder det i \$\$ 21 og 29: "Konsistoriet er berettiget til at opløse Menighedsrepræsentationen (resp. Kirkeforstanderskabet) paa Grund af «vedvarende Forsømmelse af dens Pligter« eller "anden grov Pligtstridighed«. Hvori har da denne Forsømmelse eller Pligtstridighed bestaaet? Ifølge Lo- 
vens $\$ 46$ skal Kirkeforstanderskabet have Tilsyn med Kirkens Bygninger, paase, at de er i god Stand, føre Kirkens Regnskab osv., men imod denne Paragraf har Kirkeforstanderskabet ikke gjort noget pligtstridigt. Som bekendt har de Kirkeældste modsat sig, at der indsættes tre Mindetavler i Kirken over tre Soldater, der døde eller faldt under den fransk-tyske Krig. Initiativet hertil er udgaaet fra ganske enkelte Individer, og, efter hvad vi har erfaret, af Personer, der er indvandrede i Sognet. Den ene er ansat ved Jernbanen, den anden Gendarm, muligvis har en enkelt Person til haft med Sagen at gøre, men i ethvert Tilfælde har disse ikke nogensomhelst Berettigelse til at foretage en saadan Handling, der faar Udseende af, at det sker i hele Menighedens Navn. Kirkeforstanderskabet, eller rettere sagt de Kirkeældste, da Præsten vistnok har holdt sig neutral, har fjernet Tavlerne, efter at de omtalte havde ladet dem bringe ind i Kirken. Disse Personer har støttet sig til Kirkevisitatoriet og Konsistoriet i Kiel, og man ser nu, at disse Myndigheder har billiget de omtalte Tavlers Indsættelse, og Konsistoriet har endog anset det for en grov Pligtstridighed, at de Kirkeældste har modsat sig det. Konsistoriet kan dog ikke have fundet Hjemmel for denne Anskuelse i nogen af de Paragraffer, der angaar Kirkens eller Kirkebygningernes Vedligeholdelse, men det maa vistnok støtte sig til Lovens $\$ 40$, hvori det hedder: "Kirkeforstanderskabet har den Opgave paa en besindig Maade at anvende alle hensigtssvarende Midler ligesaavel at fremme den levende Kristendom i Menigheden, som efter Evne at forhindre alt, som kan virke fordærveligt paa Sæderne og Sjælene«. Vi har forgæves ved at gennemlæse Loven kunnet finde nogen anden Paragraf, som de Kirkeældste kan have fejlet imod, at det er denne Paragraf, det gælder, finder vi bestyrket ved at læse en Artikel i det i Aabenraa udkomne Blad "Schleswigsche Volkszeitung". Denne Artikkel kaldes et Uddrag af Bjolderup Sogns Politiks Protokol og synes at hidrøre fra en gejstlig, muligvis fra en eller anden gejstlig Autoritet, thi den opfordrede de Kirkeældste til, at de skal huske Luthers Forklaring til det fjerde Bud, og minder om forskellige Skriftsteder om Underdanighed mod Øvrigheden. 
Den Opfattelse synes her at gøres gældende, at det at modsætte sig et eller andet Ønske af Autoriteterne skal betragtes som noget, der er fordærveligt for »Sæderne og Sjælene«. Muligvis er denne Opfattelse gjort gældende af de forskellige Autoriteter, af hvem de Kirkeældste er tagen i Forhør, af Herredsfogden, Landraaden, Provsten og Amtsretten. Der er jo imidlertid stor Forskel paa at undlade at imødekomme et udtalt Ønske og at foretage noget, der strider imod en Lovbestemmelse. Hvis Autoriteterne anser det for »fordærveligt for Sjælene«, at de Kirkeældste og Menigheden undlader at imødekomme deres Ønske, men disse anser det for noget sundt for Sjælene at undlade det, saa aabenbarer det den dybe Kløft, der er mellem Befolkningen og Autoriteterne, et Forhold, der vistnok er meget uheldigt, men som jo kun kan afhjælpes ved et Middel, som vi alle kender. Spørgsmaalet er altsaa, om de Kirkeældste var forpligtede til at efterkomme de den adskillige Gange baade af den ene og den anden Autoritet givne Befalinger om at tilstede Tavlernes Indsættelse. Man har sagt, at Statsadvokaten tidligere har vægret sig ved at sætte de Kirkeældste under Tiltale for, hvad de har gjort. Det nævnte Blad mener, at han nu dog vil gøre det. Saa meget er klart, at alene en Retskendelse kan afgøre, om de Kirkeældste virkelig har forset sig imod Loven. Deres Afskedigelse er ikke afgørende i saa Henseende. Sagen er under alle Omstændigheder af betydelig Interesse, da dens endelige Afgørelse vil vise, om Menighedslovens Bestemmelse om, at Menighedens Repræsentanter har Raadighed over Kirken, har noget at betyde eller ej. Naar "Flensburger Norddeutsche Zeitung" paastaar, at der gives en kejserlig Ordre til at ophænge Mindetavler i Kirkerne, da forholder det sig ikke saaledes. Kejseren har $t$ i 11 a d t, at Mindetavler i Lighed med dem, der ophængtes efter Krigen mod Napoleon I, ophænges, det er altsaa en Forvanskning af det virkelige Forhold fra "Flensburger Norddeutsche Zeitung"s Side. Endnu i Gaar maatte Advokat Bekker underkastes Forhør "wegen Anstiftens zum Vergehen des $\$ 304$ des Strafgesetzbuches«. Om der kommer noget ud af denne Klapjagt, som ogsaa, om det nyvalgte Kirkeforstanderskabs Egenskaber svarer til de høje 
Forventninger, vil Tiden vise. Imidlertid ved man saa meget, at de nyvalgte har traadt deres Børnesko og besidder en Vilje, som det vil holde svært at bøje.«

\section{Nyvalg af 4 Kirkeældste.}

Om Nyvalget af de 4 Kirkeældste fortæller Forhandlingsprotokollen følgende:

"Sket i Bjolderup den 4. Februar 1875.

Efter at Menighedsrepræsentanterne var sammenkaldte ifølge Reskript af 26. Januar 1875 fra det høje kgl. Luth. Konsistorium, og efter at det høje kgl. Kirkevisitatorium var mødt for at lede Valget af 4 nye Eldste, mødte alle Menighedsrepræsentanter med Undtagelse af Hans H. Hansen i Gaaskær, der er syg. Valget indlededes af Herr Landraaden med en Tale, hvori han paalagde Vælgerne at søge ved Valget at oprette den i Menigheden forstyrrede Fred og pleje de afdødes Minde, og af Herr Provsten ved Tale og Bøn, hvori der mindedes om det samme.

Derefter foretoges Stemmeafgivningen skriftlig, som gav efternævnte Gaardmænd Johs. Hansen, Wollerup, Martin Nissen, Wollerup, Niels Grevsen, Jollerup og Hans Lausen, Bollersleben hver 10 Stemmer, Calle Callesen, Gaaskjer 2 Stemmer, Georg Knudsen, Rawit, Hans Nissen, Wollerup, Jacob Nic. Jacobsen, Alsleben, Hans P. Paulsen, Smedager, P. Lorenzen, Bollersleben og Hans J. Hansen, Jollerup hver 1 Stemme. Hvorefter altsaa de 4 førstnævnte med hver 10 Stemmer erklæredes for valgte i de afsattes Sted.

W. C. von Levetzau.

Gøttig.

Michaelsen.

Protokolfører.»

(Ved denne Lejlighed havde Protokolføreren undtagelsesvis benyttet den tyske Skrivemaade for Byerne, formodentlig $\mathbf{i}$ Anledning af de høje Herrer, Landraadens og Provstens, Nærværelse.)

"Flensborg Avis" har den 17. Februar 1875 skrevet om Valget i Bjolderup:

"I Bjolderup er der valgt et nyt Kirkeforstanderskab, og det ærgrer "Flensburger Nachrichten", at Medlemmerne af det nye Kirkeforstanderskab uden Undtagelse er ligesaa gode danske Mænd, som deres Forgængere. Et af Medlemmerne skal selv engang have erklæret sig uduelig til at være Kommuneforstander - fordi han ikke vilde aflægge den forlangte Ed. Men derfor kunde han jo godt være skikket til Kirkeforstanderskabets Embede.» 
Den 9. Februar meddeler Kirkevisitatoriet Konsistoriet Valgresultatet og slutter denne Indberetning med, at der efter Pastor Michaelsen og Fællers Anskuelse ganske vist ikke mere vil være Opposition mod Indsættelsen af Mindetavlerne $i$ Bjolderup Kirke, men at Præsten imidlertid holder det for muligt, at de nye Kirkeældste, saafremt det blev dem paalagt at gaa imod de afsatte Kirkeældste for at inddrive de Omkostninger, som var fremkommen ved deres pligtstridige Optræden, da vilde nedlægge deres Embeder for ikke at komme i Strid med deres Naboer.

\section{Tavlerne genindsættes.}

Den 4. Marts 1875 opfordrer Konsistoriet Kirkevisitatoriet til nu at foranledige Kirkeforstanderskabet til at lade Tavlerne genindsætte med den udtrykkelige Tilføjelse, at i Tilfælde af en Nægtelse vil Indsættelsen blive foretaget uden Kirkeforstanderskabets Medvirken. Omkostningerne skal inddrages fra de tidligere Kirkeældste, saafremt dog ikke Sognets Organer skulde beslutte sig til i Fredens Interesse indenfor Menigheden endeligt at overtage Omkostningerne paa den derværende Kirkekasse.

Skulde det sidste ikke ske, og Kirkeforstanderskabet alligevel afslaa for sit Vedkommende at foretage retslige Skridt mod de tidligere Kirkeældste, saa vil man være nødt til i Henhold til Menighedsloven af 16. August $1869 \S 53$ aliena 2 at skride til Ansættelse af en "Kirchenanwalt".

Denne Anordning sendte Kirkevisitatoriet videre den 7. med følgende Skrivelse, som maa gengives ordret i Oversættelse med et Par interessante Randbemærkninger:

Aabenraa, den 7. Marts 1875.

Til Kirkeforstanderskabet for Bjolderup Sogn, pr. Adr. Formanden.

I Henhold til Anordningen fra det kgl. evg. Luth. Konsistorium paalægger vi Kirkeforstanderskabet i Bjolderup Sogn at drage Omsorg for Genindsættelsen af Mindetavlerne $i$ den derværende Kirke paa den Maade, som de har været anbragt før deres Fjernelse, idet 
vi tilføjer, at det ellers vil blive overdraget til en Mursvend at besørge det uden Kirkeforstanderskabets Medvirken.

Med Hensyn til Omkostningerne, saa skal disse inddrages fra de tidligere Kirkeældste, saafremt da ikke Menighedens Organer i Bjolderup Sogn skulde beslutte sig til i Fredens Interesse i Sognet at overtage disse Omkostninger paa Kirkekassen.

Over Udførelsen af denne Anordning fra det kgl. evg. Luth. Konsistorium imødeser vi en snarlig Meddelelse.

Det Kgl. Kirkevisitatorium.

W. C. von Levetzau. Göttig.

Som Randbemærkninger findes følgende Ordskifte mellem Provsten og Landraaden til ovenstaaende:

Provsten: Jeg holder Reguleringen for lettere og sikrere for Stifterne, vilde derfor hellere have, at vi vender hele Sagen om; paalægger Kirkeforstanderskabet at betale Omkostningerne til Gebhardt for to Gange Rejse og forgæves foretaget Arbejde og at paalægge Stifterne nu at lade Mindetavlerne indmure igen, for at de kan være sikre paa, at det vil blive gjort efter deres Smag. Paa den Maade synes jeg, Sagen ordnes bedre og lettere. For det Tilfælde, at De ikke vil, har jeg underskrevet. (Brevet til Bjolderup.)

Göttig.

Landraaden: Dette synes jeg ikke er gennemførlig, da det ikke er i Overensstemmelse med Konsistoriets Anordning. von Levetzau.

Provsten: For at afgøre Sagen paa en Gang, beder jeg om at faa en Passus med indskudt vedrørende Godtgørelsen af Omkostningerne, som er opstaaede ved de Kirkeældstes første forstyrrende Forsøg paa Indsættelsen, eller skal vi maaske først træffe mundtlig Aftale om Arrangementet for Indsættelsen og Pengepunktet med Pastor Michaelsen.

Göttig.

Landraaden: Det vilde jeg hellere overlade til Stifterne selv, da det $n$ u v rende Kirkeforstanderskab ikke har haft noget at gøre dermed. En ny mundtlig Aftale forekommer mig næppe at være nødvendig.

von Levetzau.

Her viser Göttig sig igen tydelig som den, der vil optræde skarpest mod Kirkeforstanderskabet. Landraaden holder igen, saa meget han kan. Ordskiftet giver Efterverdenen et helt godt Billede af de to Herrers forskellige Indstilling. Den nye mundtlige Aftale med Præsten, som Provsten vil have, er naturligvis et nyt mundtligt Pres.

De fire nye Kirkeældste viste sig at være af samme Anskuelse og samme Standhaftighed som de afsatte. Den 16. 
Marts holdt de det første Møde. Forhandlingsprotokollen fortæller herom følgende:

"Da Mødet var begyndt paa lovmæssig Maade, forelæste Formanden det høje Kgl. evg. Luth. Konsistoriums Anordning, der ved det Kgl. Kirkevisitatoriums Skrivelse af 7. Marts, her ankommen den 13. Marts, var bleven os meddelt. Formanden foreslog og bad de Kirkeældste, om de ikke nu kunde gaa ind paa at adlyde og lade Mindetavlerne indsætte, da Sognet dog var ked af Striden, da det var Hans Majestæt Kejserens Ønske, da det var en Ret, som de Faldnes Efterlevende havde, og da ogsaa en Indsættelse af de Kirkeældste blev billigere og vakte mindre Opsigt, end naar de skulde indsættes af andre. Særlig gjorde Formanden opmærksom paa, at der forelaa en bestemt Befaling, og at de derfor kun havde at adlyde, hvad dog vel næppe nogen vilde fortænke dem i.

Da det dog ikke syntes, at de Kirkeældste enstemmig vilde give deres Bifald dertil, saa lod Formanden afstemme om Sagen og stemte saa da først af de ovennævnte Grunde for, at Kirkeforstanderskabet skulde lade Mindetavlerne indsætte, de 4 Kirkeældste stemte derimod og erklærede, at de ikke vilde lade dem indsætte.

Formanden spurgte dernæst, om de Kirkeældste, naar Mindetavlerne blev indsatte uden deres Medvirken, da vilde være tilfreds dermed, de erklærede dertil, at de naturligvis ikke vilde tage dem ud, og var Konsistoriet $i$ den Sag højeste Autoritet, saa maatte de jo lade Sagen bero, men hvis ikke, vilde de indgive Recurs til Ministeriet og da finde sig i dettes Kendelse. Formanden gjorde nu de Kirkeældste bekendt med Kongelig Forordning af 24. September 1867, efter hvilken Kirkernes Udsmykning etc. var underlagt det Høje Kgl. Konsistorium. Dertil svarede de Kirkeældste, at Menighedsloven var udstedt senere, hvorfor de ikke kunde vide, om de ikke kunde indgive Recurs til Ministeriet.

Hvad angaar Omkostningerne ved en Genindsættelse, da erklærede de Kirkeældste, at de ikke vilde eller kunde indkræve disse hos de afgaaede Kirkeældste, men at de var villige til i den Anledning at sammenkalde Menighedsrepræsentanterne med det første, og Kirkeforstanderskabet nærede det $\mathrm{Haab}$, at disse vilde bevilge det betalt af Kirkens Kasse, ligesom de Kirkeældste ikke har noget der. imod, hvis hines Billigelse kan opnaas. Angaaende Dagen for Mødet med Menighedsrepræsentanterne blev der i dette Møde ikke taget nogen Bestemmelse. Dog skulde Formanden indkalde den med det første.»

$\mathrm{Nu}$ er Præsten aabenbart paa Myndighedernes Side. Han gjorde ikke en Gang de Kirkeældste opmærksom paa, at Recursfristen igen overskredes. Og foruden hvad denne Forhandlingsprotokol fortæller, røber Pastor Michaelsens Indbe- 
retning til Kirkevisitatoriet den 17. tydelig hans forandrede Indstilling. I denne Indberetning skriver han tilsidst: "Jeg har denne Gang ikke kunnet opnaa mere, men jeg haaber dog, og det ser ud til, at Sagen vil kunne føres igennem uden større Vanskeligheder.«

Da Recursfristen efter Konsistoriets Anordning var gaaet uden Indsigelse fra Kirkeforstanderskabets Side, kunde Indmuringen nu altsaa anordnes. Saa nu gjaldt det om at smede, mens Jernet var varmt, og Tiden toges i vare. 1 Tiden fra 1. til 3. April indsattes Tavlerne, saa da Kirkeforstanderskabet endelig havde faaet sig samlet sammen til at vedtage og afsende deres Indsigelse, ankom denne først til Aabenraa den 4. April, og nu kunde Kirkevisitatoriet den 6. April 1875 afsende følgende Skrivelse til Pastor Michaelsen:

"Idet vi i Henhold til den os tilsendte Afskrift at Protokollen af 30. f. M. bemærker, at vi ikke mere har kunnet tage Hensyn til den Recurs til Kultusministeriet, som Kirkeforstanderskabet har vedtaget Beslutning om den næunte Dag, fordi samme først har været os i Hænde den 4. ds., da Indmuringen af Mindetavlerne allerede havde fundet Sted, tilsender vi samtidig deres Velærværdighed i Henhold til vor Skrivelse af 30 . f. M. Murmester Langschwagers Regning over Indmuringen af Mindetavlerne med Paalæg om velvilligst at sørge for sammes Betaling og meddele os, at dette er sket."

Fristen var forsømt fra Kirkeforstanderskabets Side. Kirkevisitatoriet havde Formalia $i$ Orden, og naar man saa desuden har Magten til sin Raadighed, saa kan man se bort fra en Smaating som denne at maatte undvære Retten paa sin Side.

Imidlertid gik Sagen med de afsatte Kirkeældste sin Gang. Aviserne havde meddelt et Rygte om, at Statsadvokaten forst havde nægtet at tage sig af Sagen (Dannevirke 17. 2. 1875), nu er han gjort mobil. Den 13. April opfordrer han Kirkevisitatoriet i Aabenraa til at indkræve og videresende til ham Forhandlingsprotokollerne fra Kirkeforstanderskabets Møder i Bjolderup i Tiden fra Decbr. 1873 indtil Slutning af 1874. Protokollerne ønskes indsendt 8 Dage før Audiensterminen, som var ansat i Sagen til den 30. April.

Men saa sker der dette mærkelige, at man bliver betænkelig 


\section{i Konsistoriet i Kiel. Den 20. April sendes følgende Skrivelse} til Kirkevisitatoriet i Aabenraa fra Konsistoriet:

"Da de Kirkeældste i Bjolderup har indgivet Recurs til Herr Kultusministeren mod vor Anordning af 4. ds. vedrørende Genindsættelsen af Mindetavlerne i den derværende Kirke, beder vi det Kgl. Kirkevisitatorium for Aabenraa Provsti foreløbig at ville sistere den videre Udførelse af nævnte Anordning."

Man vidste selvfølgelig i Kiel, at Sagen ikke kunde holde for en saglig Kritik fra Ministeriet, hvis dette skulde vise sig mindre forstaaende for de lavere Myndigheders Tjenesteiver. Hvis ikke da Kirkevisitatoriet havde været saa hurtigt i Ven. dingen og kunnet melde Konsistoriet, at Tavlerne var indmurede, og at Præsten havde faaet de Kirkeældste til at afgive et Slags Løfte om, at naar Tavlerne først sad der, saa vilde man ikke fjerne dem igen, ja saa var Tavlerne ganske sikkert aldrig kommen ind i Kirken.

\section{Den 16. April bragte »Dannevirke følgende Artikel:}

"Efter at de nye Kirkeældste i Bjolderup Sogn ogsaa har nægtet enhver som helst Medvirken til Indsættelsen af de famøse Mindetavler $\mathrm{i}$ den derværende Kirke, er disse nu af Autoriteterne bleven indsatte imod Kirkeforstanderskabets Vilje. Konsistoriet, som meddelte Kirkeforstanderskabet Befaling til at indsætte dem under Trussel af, at de ellers vilde blive indsat uden deres Hjælp, var saa omhyggelig for "Freden " i Menigheden, at det henstillede til det nye Kirkeforstanderskab, om dette vilde lade Omkostningerne ved Indsættelsen udrede af - Menighedskassen, istedetfor at forlange dem erstattet af de gamle Kirkeældste. Man ved ikke rigtig, om man skal le eller græde over denne Omhyggelighed for ikke at forstyrre "Freden i Menigheden", naar der i samme Aandedrag paabydes en Foranstaltning, som for mange Aar fuldstændig vil tilintetgøre Freden i Menigheden - en Foranstaltning, der ikke geraader nogen i Verden til Nytte, Gavn eller Ære, men kun konstaterer, hvorledes i vore Dage et forsvindende Mindretal kan opnaa at faa politiske Drillerier sat i Scene. De nye Kirkeældste har naturligvis indanket Konsistoriets Anordning for Ministeriet, saa der er jo endnu altid en Mulighed for at faa den ophævet. Samtidig har Statsadvokaten faaet en Anklage lavet i Stand mod de Kirkeældste, som anklages for Krænkelse af offentlige Mindesmærker.De anklagede er Gaardejerne Mathias Knudsen i Hjolderup, Johan Fr. Andresen og Jens Petersen i Vollerup og Jørgen Jørgensen i Bolderslev og endelig Advokat Bekker i Aabenraa. Sidstnævnte som Anstifter til hele Komplottet. Denne interessante Sag skal til Forhandling for Straffekammeret i Flensborg den 30. April. Hvorledes 
end Sagen ender, saa er den et uforkasteligt Vidnesbyrd om Bjolderup Sogns urokkelige danske Sindelag og dets sejge Modstand mod "Fremmed Sæd og Skik".

Denne Artikel stod den 19. April i »Fædrelandet« og er maaske ad denne Vej først kommet til Konsistoriets Kundskab, efter at Skrivelsen af 20. var afsendt. Den 26. April afsendtes følgende Telegram fra Konsistoriet: "Kirkevisitatorium Aabenraa Provsti, Telegrafisk Meddelelse udbedes, om det er rigtigt, som Avisefterretninger paastaar, at Mindetavlerne allerede igen er indsatte". Herpaa svarede Provsten: "Mindetavlerne indsat af os fra 1. til 3. April, Reklamation fulgte den 4. vor Beretning afsendt i Gaar.« Den her omtalte Beretning er følgende Brev af 23. April til Konsistoriet:

"Kirkevisitatoriet undlader ikke at indberette, at Mindetavlerne, efter at Pastor Michaelsen under 17. Marts havde meddelt os, at Kirkeforstanderskabet ved Majoritetsbeslutning havde nægtet at lade Genindsættelsen af Tavlerne foretage, efter Anordning herfra af 30. Marts, allerede er indsat, medens Kirkevisitatoriet først modtog Meddelelsen om Beslutningen om at indgive Recurs den 4. April.«

Man kan tænke sig til, hvorledes denne fuldbyrdede Kendsgerning maa have virket befriende paa de Herrer i Kiel, man har nok turdet haabe paa, at Ministeriet vilde være noget betænkelig ved at omstøde fuldbyrdede Kendsgerninger og har selvfølgelig sørget for at faa Ministeriet underrettet om de foreliggende Kendsgerninger, inden dette afsendte Svar paa Kirkeforstanderskabets indsendte Recurs. En senere Skrivelse fra Ministeriet henviser til Konsistoriets Skrivelse af 30. April.

\section{Ministeriets Afgørelse.}

Den 10. Juni har Ministeriet i Berlin endelig truffet en Afgørelse, som man vil læse med megen Interesse, særligt den sidste Del, som jo imidlertid, som den Næse til Konsistorium og Kirkevisitatorium, den var, kun naaede til disse.Myndigheders Kundskab og først nu drages frem for Offentligheden. Skrivelsen lyder i sin Helhed i Oversættelse: 
"Kultusministeriet for Undervis-

Berlin, d. 10. Juni 1875.

nings- og Medicinalanliggender.

Jour. Nr. 2666 G. I.

Til Kirkeforstanderskabet $\mathrm{i}$ Bjolderup.

Som Svar paa Deres Skrivelse af 1. og 6. April meddeler jeg Kirkeforstanderskabet, idet jeg sender Bilagene tilbage, at jeg paa Sagens nuværende Standpunkt, efter at Mindetavlerne, som var opstillet med Kirkevisitatoriets Tilladelse, men saa fjernet igen paa ulovlig Maade (ordnungswidrig) og nu igen er indmurede i Kirken, saa meget mindre finder mig foranlediget til at tilbagekalde de af Kirkevisitatoriet og det Kgl. Konsistorium trufne Anordninger, da der hverken af det tidligere Kirkeforstanderskab eller i den foreliggende Skrivelse er fremført særlige saglige Grunde, som kunde retfærdiggøre Tilbagevisningen af det af Menighedsmedlemmer stillede Andragende om Anbringelse af Mindetavlerne.

E. B.

Førster.

Afskrift tilsendes det Kgl. Konsistorium til Efterretning som Svar paa Indberetning af 30. 4. d. A. Journal Nr. 607/75.

Det Kgl. Konsistorium gør vi dog opmærksom paa, at Kejserens og Kongens Majestæt gennem allerhøjeste Kabinetsordre af 2. Septbr. 1873 ganske vist har givet sin allerhøjeste Tilladelse til at anbringe Mindetavler i Kirker og derved kundgjort $\varnothing$ nsket om, at Anbringelsen maatte blive almindelig gennem frivillig Offervillie (Liebesthätigkeit) i Menigheden, men eventuelt at fremtvinge en Forpligtelse i den Henseende er ikke paalagt Menighederne, og maa det derfor for Fremtiden $i$ eventuelt lignende Tilfælde have at forblive ved de Beslutninger, som Menighedens Organer vedtager.

E. B.

Førster."

Den Del af Skrivelsen, som var adresseret til Kirkeforstanderskabet i Bjolderup, giver dette en Sludder for en Sladder. Men ligesaa intetsigende, som denne første Del er, ligesaa interessant er den sidste Del, som var adresseret til Kirkevisitatoriet og Konsistoriet. Det fastslaas eftertrykkeligt, at Kirkeforstanderskabet havde haft Ret til at nægte Anbringelsen af Tavlerne.

Naar man nu har læst denne ministerielle Besked, kan man daarlig forstaa, at Sagen trods alt kunde udvikle sig, som den senere hen gjorde.

I Bjolderup stod man noget uforstaaende overfor den modtagne ministerielle Besked, og med Rette. De Kirkeældste forlangte et Møde om Sagen, som blev fastsat til den 23. Juni 1875. Herom beretter Protokollen, at de onskede, da det af Ministeriet givne Svar ikke gav den fuld Klarhed, og da der nu var kom- 
men en ny Sag til, nemlig Kirkens Istandsættelse omkring Tavlerne, at indgive et nyt Andragende til Ministeriet for overfor dette at give en klarere Fremstilling af Sagen og hos dette at søge om deres formentlige Ret og tillige for at faa Klarhed over deres Pligter og Rettigheder som Kirkeældste. Da Kirkeældste Johannes Hansen i Korthed havde foreslaaet ovenstaaende, spurgte riet de Kirkeældste fra Vollerup J. Hansen og M. Nissen og forlangte da for disse udstedt en Fuldmagt $\mathrm{i}$ Kirkeforstanderskabets Navn til at udføre dette.

Desværre forefindes der intet om, hvorvidt denne Forespørgsel er bleven indsendt til Ministeriet. I Forhandlingsprotokollen er den ikke senere omtalt, og Kirkevisitatoriets Akter viser heller intet herom hverken fra den ene eller anden Side. Det er lidt mystisk.

\section{Den nye Sag.}

Paa Kirkeforstanderskabets sidst omtalte Møde var der Tale om en ny Sag, Kirkemurens Istandsættelse omkring Tavlerne. Da Langschwager havde indsat Tavlerne i Kirken de første Dage i April, har Provsten formodentlig paalagt ham at sørge for at faa Arbejdet tilside hurtigst muligt. Han er nemlig kommen lidt let fra det, idet Muren rundt omkring Tavlerne var baade snavset og ikke afpudset. Men da Kirkevisitatoriet havde ladet Tavlerne indsætte, saa maatte det ogsaa være dettes Sag at lade Resten af Arbejdet gøre, det var ialt Fald Kirkeforstanderskabet uvedkommende, og selvfølgelig lod man det ligge, indtil rette Vedkommende fandt sig beføjet til at faa det i Orden.

Om en Kirkevisitation fortæller wFlensborg Avis« den 25. Juni 1875:

"Den uhyggelige Tavlehistorie i Bjolderup har naturligvis hos Menighedens Medlemmer fremkaldt en bitter Stemning mod Autoriteterne, hvad jo ikke kan være anderledes, efter hvad der er foregaaet, og denne Stemning vil efter al Sandsynlighed træde frem paa samme Maade i Fremtiden. Ved en Visitats i Mandags modte der næsten ingen i Kirken. En Reparation, som Provsten ansaa for nødvendig, blev pure nægtet af de Kirkeældste.« 
Det hele kunde se ud som et nogenlunde uskyldigt Tovtrækkeri, men det er det absolut ikke. Saalænge Kirkeforstanderskabet holdt sig afvisende overfor alt, hvad der vedrørte Tavlerne, havde de jo faktisk ikke anerkendt Tavlernes Berettigelse, og det var Göttig klog nok til at indse. Man kunde jo aldrig vide, fra hvilken Side Faren næste Gang kunde vise sig. Det er ganske interessant at lægge Mærke til, hvor stærkt det laa Provsten paa Sinde at faa denne sidste Del af hans store Kamp bragt til en tilfredsstillende Afslutning, saa Sejren endelig kunde betragtes som vis. Men Forhandlingsmand har han ikke været, han har været ærlig i al sin Brutalitet. Det viser hans Optræden under Kirkevisitationen i Bjolderup. Saa har Pastor Michaelsen været hans Overmand, han kunde meddele sine Foresatte: "at han ikke har kunnet opnaa mere denne Gang «, eller en anden Gang: "at han bestemt troede og haabede at kunne bringe Sagen til en tilfredsstillende Afslutning, naar bare man vil give ham Tid; han fik Ret. Men Pastor Michaelsen elskede ikke de Mænd, der havde Magten over ham og tvang ham til at støtte sig i Kampen mod dem, der i enhver Henseende stod ham nærmest. Det kan virke oplivende at læse hans Indberetninger til Kirkevisitatoriet, hvor han i al sin Underdanighed kan faa anbragt en bidende Spydighed til de høje Foresatte. Hans Intelligens oversteg nok ogsaa Provstens, om hvem der fortælles de mest haarrejsende Historier fra hans Visitatser, en af dem er netop her fra Bjolderup Kirke, fortalt mig af Hans Lorensen fra Bolderslev fra en Visitats i Firserne, hvor han kom med følgende Spørgsmaal til en af de største Drenge: "Kan du kalde (han mente altsaa nævne) mig en Jomfru?"

Den 16. Marts 1875 havde de fire nye Kirkeældste som ovenfor omtalt bestemt afvist at lade Tavlerne indsætte, men lovet, at de ikke vilde tage dem ud igen, hvis de blev indsat, men derimod med Menighedsrepræsentanternes Samtykke søge Omkostningerne dækket af Kirkekassen. Paa Kirkeforstanderskabets Møde den 30. Marts berørtes denne Side af Sagen slet ikke. Den 3. Maj deltog Repræsentanterne i Kirkeforstanderskabets Møde. Her vedtog man, at Beslutningen angaaende $\mathrm{Be}-$ 
talingen foreløbig skulde udskydes. Saa kom Ministeriets Skrivelse, i hvilken Anledning man samledes den 23. Juni, men Spørgsmaalet om Betalingen berørtes ikke paa dette Møde. Først den 11. Januar næste Aar rejstes Spørgsmaalet paa det Møde, som hele Kollegiet holdt den Dag. Det første Spørgsmaal fra Formanden lød, om de vilde bevillige Betalingen for Indsættelsen af Mindetavlerne af Kirkens Kasse, dette nægtede de e $\mathrm{n}$ s t e m m i g t. Det næste Spørgsmaal var da, om de vilde gaa ind paa, saafremt de, der første Gang havde ladet Tavlerne indsætte, nu ogsaa betalte denne Indsættelse, da at lade Tavlerne vedligeholde tilligemed Omgivelserne og i det hele betragte Striden som endt. Det te $\mathrm{n}$ æg tede Flertallet. Her har saa igen den ene af Repræsentanterne svigtet sine Kolleger. Men for de øvrige 15 var Standpunktet rent og klart. Man var ikke naaet et Skridt videre med dette standhaftige - i Myndighedernes Øjne naturligvis stædige - Kirkeforstanderskab, og man har staaet nogenlunde magtesløs overfor samme, skønt "Sejren" var vundet, og Tavlerne hang paa Væggen. Men saa skete der noget, der paa engang drejede Sagen ind i en helt ny Gade, dog derom -senere.

Provsten havde, da de Kirkeældste nægtede at lade Kirkemuren rense og istandsæette, beordret Langschwager i Aabenraa til at gøre dette Arbejde. Men helt glat skulde dette nu heller ikke gaa. Den 10. Januar 1876 maatte Provsten meddele Landraaden følgende:

"I Sommer har Murmester Langschwager indsendt en Regning for Indmuring af Mindetavlerne i Bjolderup Kirke. Denne er endnu ikke betalt. Jeg beder Dem om at undersøge Sagen og anordne det fornødne.

Ved den sidste Visitation i Bjolderup Kirke forefandt jeg Kirkemuren rundt om Mindetavlerne tilsnavset af Muringen, $i$ Grunden til almindelig Forargelse. In gen af de stridende Parter vilde sørge for Rengøringen, idet hver skød det over paa Modparten.

Af den Grund paalagde jeg Langschwager at sørge for at faa det ufuldendte Arbejde gjort ordentligt i Stand. Da han ikke har haft Tid før, er han først kommen til det nu. For 8 Dage siden sendte han en dygtig og ordentlig Mand derud for at overkalke Rammen og Pletterne og rense det hele. 
Denne Mand afvistes imidlertid af Præsten og de Kirkeældste, og man nægtede at udlevere Kirkenøglen til ham. Det er mig ganske ubegribeligt. Hvad skal vi gore ved Sagen? Regningen skulde ogsaa gerne betales."

Paa denne Forespørgsel sendte Pastor Michaelsen følgende kostelige Svar den 19. Januar 1876:

"Bjolderup Pastorat indberetter til det høje Kgl. Kirkevisitatorium i Aabenraa vedrørende Murmester Langschwagers Beskyldninger:

I den omtalte Sag tillader jeg mig underdanigst at indberette, at Repræsentanterne i Møderno efter Mindetavlernes Indmuring har stemt for at opsætte Sagen. Ved det sidste Møde (11. Januar) derimod har alle enstemmigt nægtet Betalingen.

Jeg har henvendt mig til de tidligere Kirkeældste og haaber, maaske i de nærmeste Dage, senest i Begyndelsen af Februar, naar de tidligere Kirkeældste vender tilbage (fra deres Fængselsophold!), at kunne betale Regningen.

En foregiven Murersvend fra Langschwager har jeg personligt ikke kunnet aabne Kirkedøren for, da han mødte frem uden nogensomhelst Legitimation, og i det hele aabnes Kirkedøren ikke for en fremmed Svend af mig uden paa Befaling af de mig foresatte Myndigheder. Iøvrigt har jeg ikke forment ham Adgang til Kirken. Med Murermesterens Foregivende, at et Arbejde, for hvilket han allerede har udstedt Regning den 4. April og nu i Januar 1876, betragtes som ikke færdigt, kan jeg ikke undskylde mig med.

Iøvrigt haaber jeg at bringe Sagen i Orden, naar kun det høje Kirkevisitatorium vil og kan indrømme mig den nødvendige Tid, saaledes at Arbejdet ved Mindetavlerne og deres Omgivelser herefter ligesom den øvrige Del af Kirken kan blive foretaget af Kirkeforstanderskabet. Hvis ikke, er jeg selvfølgelig rede til at lystre enhver Ordre fra det høje Kirkevisitatorium.

Underdanigt, Michaelsen.»

Den 24. Januar svarede saa Kirkevisitatoriet, at man nu indtil Midten af Februar imødesaa Præstens Meddelelse, om Regningen til Langschwager er betalt samt en nærmere Forklaring, paa hvilken Maade og til hvilket Tidspunkt Præsten mente at faa Rensningen og Afpudsningen af Tavlerne og Muren rundt omkring færdig, som man havde forhindret ved Bortvisningen af Murersvenden. Nu matte man vente, at Præsten vilde vise, at det var ham virkelig magtpaaliggende at faa denne ubehagelige Sag bragt til Afslutning, for at Skinnet dog ikke maa være 
imod Præsten! Kampen er saa sandt ikke uden Humor, og Præstens Svar den 1. Februar gemmer ikke mindst af dette.

Han begynder Svaret med, at han hverken kan angive en bestemt Maade eller et bestemt Tidspunkt for Mindetavlernes Rensning og Afpudsning.

"Jeg har det Haab», fortsætter han, "at jeg sandsynligvis til Foraaret ved den næste aarlige Overkalkning af Kirken kan satte det igennem ogsaa at lade Vaggen omkring Mindetavlerne rense og overkalke. Med Hensyn til Slutningsbemærkningerne tillader jog mig at indberette, at en meget daarlig klædt svend har været herude, som ogsaa foregav at vere sendt af Langschwager. Hos mig har han ikke navnt sit Navn. Hos de Kirkeældste har han nok kaldt sig Wol-

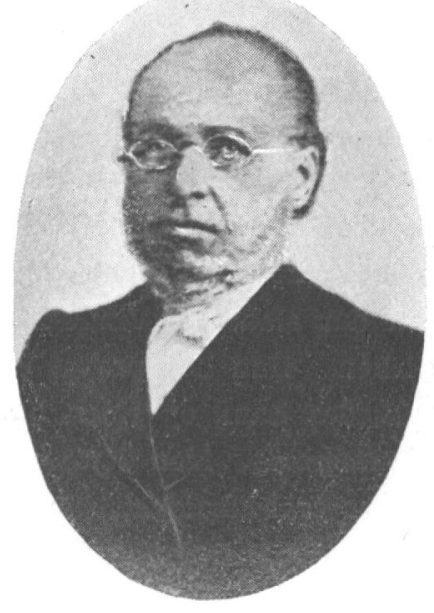

Pastor Michaelsen. gast. Han mente, at det var mig, der havde sendt Bud efter ham, og det nægtede jeg. Han har ikke forlangt noget af mig. Iøvrigt sagde jeg til ham, at Kirkenøglen skulde hentes hos Degnen. Jeg har ikke set mig foranlediget til at føre ham op i Kirken, da jeg var uden enhver Anvisning, og han var uden enhver Legitimation. At dette Arbejde igen var overgivet til Langschwager, har jeg ikke erfaret noget om. Ved Kirkevisitationen her den 24. Juni paalagde hans Højærværdighed de Kirkeældste at lade Stedet afpudse og rense. Jeg har villet gennemføre Afpudsningen og Rensningen ved hvert Møde siden da, det er ikke lykkedes for mig endnu, dog som tidligere sagt, jeg har det Haab, at det vil lykkes i Foraaret. Kan Sagen ikke udskydes saa længe, er jeg selvfølgelig rede til at lystre enhver Befaling fra det høje Kgl. Kirkevisitatorium.»

\section{Indbruddet i Bjolderup Kirke.}

Man var faktisk kørt fuldstændig fast med Kirkeforstanderskebet paa Grund af dettes Standhaftighed, og hvem ved, hvordan det hele kunde have endt endnu, hvis Kirkekollegiet havde holdt fast paa, at Tavlerne og alt, hvad der faldt sammen med dem, var dem aldeles uvedkommende. Konsistoriet havde ganske vist truet med at indsætte en "Kirchenanwalt«, hvis man 
ikke makkede ret, men efter Ministeriets Skrivelse af 10. Juni er det nu langtfra sikkert, at denne Trussel var bleven virkeliggjort. Der maatte noget helt nyt til, og her kom "Tilfældet« i høj Grad Myndighederne til Hjælp.

Den 27. Januar sendte Pastor Michaelsen følgende opsigtsvækkende Melding til Kirkevisitatoriet:

"Det høje Kgl. Kirkevisitatorium sender jeg den pligtmæssige Melding, at Mindetavlerne er bleven beskadiget paa forbryderisk Maade i en af Nætterne mellem den 23. og i Dag den 27. ds. Gerningsmanden har slaaet to Vinduesruder itu og ad den Vej banet sig Vej til Kirken. Han har prøvet paa at tage Tavlerne ned, og det er ikke lykkedes ham, og siden har han prøvet paa at ødelægge dem ved Hammerslag. Men dette er heller ikke lykkedes, kun Rammen og to Tavler er beskadiget. Sagen er meldt til Politiet.»

Nu kom der nok Gang i Sagerne. Landraaden sendte Indberetning til Regeringen i Slesvig:

"Jeg undlader ikke at meddele den Kgl. Regering den Melding, som er tilgaaet Kirkevisitatoriet, om at der i Tiden fra den 23. ds. til den 27. ds., .da der afholdtes en Begravelse, er forøvet et Indbrud t Bjolderup Kirke for at ødelægge Mindetavlerne. Efter den straks. iværksatte Undersøgelse har Gerningsmanden skaffet sig Adgang til Kirken ved at slaa et Par Ruder itu i det saakaldte Vaabenhus, og har saa med et Stykke Jern, som han har fundet i Kirken, forsøgt at slaa Tavlerne i Stykker, resp. prøvet paa at slaa dem ned. Bestemte Indicier mod Gerningsmanden foreligger endnu ikke. Da Gendarm Gutjahr, som nu or stationeret i Bolderslev, endnu kun er lidet kendt og ikke er det danske Sprog mægtig, har jeg sendt Gendarm IIenningsen, som indtil for kort Tid siden har været stationeret $i$ Boldersler og derfor sidder inde med nøje Person-Kendskab, over for at hjælpe Gendarm Gutjahr med I'ndersogelserne..

Selvfølgelig fløj Nyheden om Indbruddet og Voldsdaaden ud over Landet. Den første Meddelelse herom ser man i "Dannevirke" den 31. Januar 1876, hvor det meddeltes, at Mindetavlerne er aldeles ødelagte.

Den 2. Februar har Bladet en ny Artikel herom:

"Indbruddet i Bjolderup Kirke indskrænker sig, efter hvad den straks efter Gerningens Udwvelse af Herredsfoged Jensen paa Stedet foretagne Undersøgelse skal have godtgjort, til, at en Mand gennem et Vindue er trangt ind i Kirken og har forsøgt at løse Mindetavlerne 
fra Væggen, hvad der imidlertid ikke er lykkedes ham. Tavlen er ikke ødelagt, saaledes som Rygtet først omtalte, men kun lidt beskadiget i Kanterne. Gerningsmanden er endnu ikke opdaget, uagtet der fra Autoriteternes Side er udfoldet stor Iver. Efter hvad "Flensborg Avis" vil have erfaret, skal den Bjolderup Kirke nærmest boende Mand samme Nat, som Indbruddet skete, have hørt nogle berusede Personer drage forbi, syngende en tysk Vise."

Detyske Lokalblademelderaldelesintetom I n d b r u d d e t. - Det varede dog ikke længe, inden Sagen ogsaa blev drøftet $i$ større tyske Blade.

\section{"Fædrelandet« skriver den 13. Februar efter "Dannevirke«:}

"Den venlige Tone, som "Nationalzeitung" $\mathrm{i}$ forrige Maaned anslog overfor Danskheden, er hurtigt slaaet om til det modsatte, og Indbruddet $\mathrm{i}$ Bjolderup Kirke har givet Bladet Anledning til et uhort voldsomt Udfald imod Danskheden i Slesvig. Det har i det mindste tilladt en Brevskriver fra Slesvig-Holsten at besudle den danske Presse og Danskheden paa en Maade, som ligefrem er uværdigt for et saa stort og iøvrigt anset Blad. Korrespondancen er saalydende: "De ophidsenrle Artikler i "Dannevirke" og dens danske Kolleger i Nordslesvig er ikke forbleven uden Virkning. Natten til den 28. f. M. er danske Fanatikere trængte ind i Bjolderup kirke og har fuldstændig odelagt Mindetavlen for de faldne tyske Krigere. Forbitrelsen over denne Udaad er navnlig stor i nordslesvigske tyske Kredse, og det er ligesaa forklarligt som tilgiveligt, naar den berettigede Uvilje hovedsagelig vender sig imod de intellektuelle Ophavsmænd til Gerningen, de danske Blade i Nordslesvig. "Kieler Zeitung" kan gerne tillade sig at sige, at man ikke kan tillægge "Dannevirke og Konsorter Gerningen. I Nordslesvig ved man bedre end i Kiels Forstad, til hvem man skal henføre den seneste Kirke-Vanhelligelse, og kun den, der selv har levet blandt de Danske, de nationaldanske saavel som de nordslesvigske, forstaar den Vrede, som i Dag kommer til Orde i den Artikel, som "Flensburger Norddeutsche-Zeitung" (Dannevirkes Anmærkning: hvori den danske Presse kaldes "das niederträchtige dänische Gesindel «) ofrer paa Skandselsgerningen i Bjolderup. Men paa vore tyske Landsmand saavel som paa Udlandet vil denne Daad i mange Retninger aabne Ojnene med Hensyn til Danskheden i og udenfor den tyske Landsgrænse". - "Dannevirke" nodlargger den bestemteste Indsigelse mod dette uberettigede Angreb og gor blandt andet galdende, wat det muligt er en dansk, der har begalaet denne Gerning, men ht det ligesuagodt kan va'e en tysk Fanatiker, der har gjort det. Flonsborg-I.øvens fdelæggelse viser, hvad tysk Fanatisme kan tillade sig."

Som man ser, gik Bølgerne højt. Man maa lægge Mærke til folgende: De lokale tyske Blade forholder sig tavse. »Kieler- 
Zeitung" har Mod til at tage den danske Presse i Forsvar. Det er kun Blade udenfor Provinsen, som har været helt ukendte med Forholdene, man har kunnet bruge til gennem en "Brevskriver fra Slesvig-Holsten" at ophidse Tyskerne mod de utaknemmelige og fanatiske Danskere, som saa lidet paaskønnede, hvad godt Tyskerne havde gjort dem efter at have frelst dem fra Fremmedaaget, og nu drev deres Fanatisme saavidt, at de endog vanhelligede Kirken af Had til tyske Mindesmærker!

Hvad var der da sket? En Mand var brudt ind igennem et Vindue i Vaabenhuset, hvorved han havde saaret sine Fingre. Man kunde spore hans Gang i Kirken. Der var Bloddraaber paa Gulvet op til Alteret. (Det sidste har en af mine Hjemmelsmænd fortalt mig.) Manden har fundet en Jernstang, som henlaa i Kirken, andre mener, han har brugt Nøglen fra Vaabenhusdøren, og med denne har han prøvet paa at bryde Tavlen ud af Muren. Det har ikke været muligt for ham, kun Cementrammen, der omgiver Tavlerne, var bleven beskadiget. Af de tre Tavler havde en, den højre, faaet 15 til $20 \mathrm{Slag}$, som har fremkaldt smaa Fordybninger, den mellemste 2 til 3 Slag, medens den venstre var helt ubeskadiget. Da ingen af Slagene har fremkaldt andet end smaa Fordybninger - der er nemlig øjensynlig ikke foretaget noget med Tavlerne efter Attentatet, man kan stadig se Fordybningerne - kan Slagene ikke have været særlig kraftige, der skal da ikke saa forfærdelig meget til at slaa en Marmorplade i Stykker med en Jernstang.

Man havde ingen mistænkt. Det eneste Spor, man havde foreløbigt, var jo, at Misdæderen havde blødt i Kirken, altsaa maatte have saaret sine Fingre ved Indbruddet. Gendarm Henningsen fæstede da ogsaa sin Opmærksomhed ved denne Omstændighed og beordrede Gaardejer Peter Lorensen fra Bolderslev til at køre ham til Havsted, hvor man havde hørt om en Mand, som havde daarlige Fingre. Det er Sønnen Hans Lorensen, som har fortalt mig det. Nu gjaldt det altsaa om at finde alle de Folk, som sad med daarlige Fingre, og se, om de kunde gøre rede for sig. Alle disse Anstrengelser førte dog ikke til noget Resultat, mærkeligt nok. For der er jo næppe nogen Tvivl 
om, at Snakken er gaaet livligt i Sognet. At Danskerne skulde have grebet til den Udvej, for at slippe af med de forhadte Tavler, synes ikke sandsynligt. Det har ligget dem ligesaa fjernt den Gang som nu. Hvis man havde alvorlig Mistanke til nogen ude blandt Befolkningen, kunde det næppe forblive skjult for de emsige Myndigheder. Der er af gamle, som har oplevet denne Tid, og kan mindes noget derfra, fremsat Gisninger om, at en Snedker Hans Peter Jørgensen fra Raved, ogsaa kaldet Rytter, skulde være Manden. Han var stærkt hengiven til Drik og er senere havnet paa Fattiggaarden i Todsbøl, her endte han sine Dage efter et Drikkegilde med andre Fattighuslemmer ved at hænge sig. Man mente, at denne Mand skulde være blevet betalt for at begaa Udaaden. Andre har nævnt Urmager Lund fra Bjolderup. Denne Mand var meget indesluttet og talte sjældent med Folk. Der er blot det mærkelige, at det maa være ham, som "Flensborg Avis« hentyder til, der har hørt Tyskere komme syngende forbi Kirkegaarden og hans Hus en af de Nætter, da Udaaden maa være sket. Men altsaa Gisninger, som Myndighederne dog vistnok ogsaa maa have hørt eller faaet et lille Nys om. Derfor tror jeg ikke rigtig paa dem, der er ingen, der ved noget om, at de to ovennævnte er bleven taget i Forhør, Myndighederne kan $i$ alt Fald ikke have overset "Flensborg Avis«s Hentydning til, at man havde Tyskerne mistænkt.

De, der i Virkeligheden høstede Gavn af Begivenheden var absolut Tyskerne. Denne Udaad, som alle Aviser og alle Danskere kaldte den, satte Sindene stærkt i Bevægelse og fremkaldte en Stemning, som Tyskerne vidste at benytte sig af. Den forste Følge var, at Pastor Michaelsen kunde meddele Kirkevisitatoriet under den 12. Febr., at Regningen til Langschwager var betalt den 10. Febr. Den 14. Febr. sendte Kirkevisitatoriet følgende Skrivelse til Pastor Michaelsen:

"Af Deres behagelige Indberetning af 12 . ds. ser vi (i Udkastet er Ordene "mit Befriedigung" udstreget), at Regningen for Indmuringen nu er betalt. Saa meget mere haaber vi nu, at nu ogsaa Istandsættelsen af Mindetavlerne og deres Omgivelse paa en værdig Maade maa tages op af Kirkeforstanderskabet, for saaledes paa en efter- 
trykkelig Maade at lægge dettes Misbilligelse over Indbruddet i Kirken for Dagen."

Kirkevisitatoriet regnede vel nu med, at Kirkeforstanderskabet vilde være mere modtageligt for dettes Ønsker. Mødet den 21. Februar viste dog endnu noget andet. Formanden oplæste her Kirkevisitatoriets Skrivelse af 14. ds. og anbefalede varmt og foreslog, at Kirkeforstanderskabet skulde lade Tavlerne istandsætte, baade for at vise sin Misbilligelse af det skete og for at faa Ende paa Sagen. De Kirkeældste svarede nej! Hvad der saa er sket i Dagene mellem den 21. og 26: Febr. vides ikke. Den 26. Febr. var Kirkekollegiet kaldt ind til et nyt Møde. Her oplæste Formanden igen Skrivelsen af 14. Febr. og foreslog igen, at Kirkeforstanderskabet skulde lade Mindetavlerne i Kirken istandgøre, for derved paa en smuk Maade at misbillige den Udaad, der havde fundet Sted og saaledes række Haand til Forlig og Enighed i Menigheden og derved atter faa Kirkens Arbejde ind under Kirkeforstanderskabets Raadighed.

Det gik alle enstemmigt ind paa, men dog kun saaledes, at de Kirkeældste og Menighedsrepræsentanter udtrykkeligt bemærkede, at de ikke derved anerkendte Tavlerne. De vilde desuden ved samme Lejlighed have Klarhed over og Oplysning om følgende Punkter for derved at forhindre enhver Strid og Fare i Fremtiden:

1) Har efter Menighedsloven nogle enkelte i Menigheden, naar disse ikke er valgte til Kirkeældste eller Repræsentanter, Lov til med højere Tilladelse at foretage Arbejder i Kirken, og skal ikke alle Arbejder ved de kirkelige Bygninger udføres af Kirkeforstanderskabet?

2) Kan den kirkelige Øvrighed, naar der ikke foreligger en Lov, der skal udføres, eller der ikke kan paavises noget, der er forsømt, der skal udføres, ved egne dertil kaldede Arbejdere lade Arbejdet udføre uden de Kirkeældstes Samtykke, og skal disse ikke, naar de nægter Lydighed, afsættes og andre vælges i deres Sted, der vil lyde og udføre de befalede Arbejder?

Nu var man altsaa endelig gaaet med til at istandsætte Tavlerne, ganske vist med Forbehold. De ovenanførte Udtalelser om Kirkeforstanderskabets Forbehold og deres to fremsatte Spørgsmaal om denne Sag blev de sidste Udtalelser, som forefindes fra 
Kirkeforstanderskabet i Protokollen. Tavlerne hænger paa Væggen, men Menigheden anerkender ikke deres Berettigelse!

Som Provsten har ladet haant om alle deres højtidelige Erklæringer om, at de ikke vilde tillade Anbringelsen af Tavlerne i Kirken, har den sidste Erklæring sikkert heller ikke gjort meget Indtryk paa ham.

Endnu samme Dag, den 26. Febr., sendte Pastor Michaelsen Meddelelse om Mødets glædelige Udfald. Dermed synes Sagen at have tabt al Interesse for Kirkevisitatoriet. Der forefindes intet mere i Akterne om, hvad Undersøgelserne efter Kirke-Ransmanden har ført til. Der findes intet om senere Indberetninger til Regeringen eller Konsistoriet. Og der findes heller intet om, hvorvidt man muligvis nu har standset Sagen. Den er tilsyneladende løbet ud i Sandet. Nu var Sejren vundet. Tavlerne hang, hvor Provst Göttig onskede det. Kirkeforstanderskabet havde endelig erklæret sig rede til at lade dem og Muren istandsætte. Langschwager havde faaet sin Regning betalt. Og saa skulde der endda komme et lille Eftersmæk, som nærmest virker morsomt. Stenhugger Gebhardt, Tavlernes Skaber, mødte frem med en lille Regning, som han onskede Kirkevisitatoriets Hjælp til Inddrivning af, idet han til dette skrev den 12. Juni:

Vedlagt tillader jeg mig at fremsende en Regning paa 9 Daler 27,- Mark, som er fremkommen ved Sagen med Mindetavlerne i Bjolderup, med Bøn om, at Kirkevisitatoriet velvilligst vil hjælpe mig til mit Tilgodehavende, da jeg ikke kan faa det paa anden Maade. Til Belysning af Sagen tillader jeg mig at bemærke, at Regningen stammer fra min forste Rejse til Bjolderup Kirke.

Underdanigst H. F. Gebhardt.

Provsten noterer hertil: Saavidt jeg ved, var denne Rejse den første for at sætte Tavlerne ind, hvis dette er Tilfældet, saa maa han holde sig til den, der har bestilt ham, om det har været Simon Johannsen, ved jeg ikke. Eller har vi anordnet denne første Rejse. Gøttig. hannsen, ved jeg ikke. Eller har vi anordnet denne første Rejse?

Göttig.

Kirkevisitatoriet sendte følgende Svar til Gebhardt: „Paa Deres Andragende undlader vi ikke at svare, idet vi tilbagesender Deres Bilag, at De for den omhandlede Regnings Vedkommende maa holde Dem til den, som har bestilt dette Arbejde af Dem. Os er Sagen uvedkommende." 
Det var denne Regning, som Provsten vilde have paatvunget Kirkeforstanderskabet allerede den 7. Marts i sit Replikskifte med Landraaden, men ikke kunde faa denne med til. Gebhardt maa altsaa nu henvende sig til S. Johannsen i Vollerup, vel sagtens til lige ringe Glæde for begge Parter. Men Kirkevisitatoriet har dog ikke haft Mod til endnu engang at gaa til Kirkeforstanderskabet i den Anledning, det vil sige, det har vel nok været Landraaden, som har holdt igen.

\section{Den rejste Straffesag.}

For Resten rejstes der selvfølgelig Klage mod de afsatte Kirkeældste.

Om selve Straffesagen foreligger der kun meget lidt i Akterne i Aabenraa, ikke andet end Brevvekslingen mellem Statsadvokaten i Flensborg og Kirkevisitatoriet i Aabenraa om Indkrævningen af Protokollen fra Bjolderup Kirkeforstanderskab. Jeg har maattet holde mig til det, som Aviserne har bragt om Sagen. De første Bemærkninger herom findes $i$ en længere Artikel i Dannevirke den 16. April 1875, som fortæller, at Statsadvokaten har rejst Sag mod de 4 Kirkeældste for "Krænkelse af offentlige Mindesmærker", samt mod Advokat Bekker i Aabenraa som "Anstifter til hele Komplottet".

Den første Termin afholdtes ved Kredsretten i Flensborg den 28. April, hvor ifølge "Flensborg Avis« var mødt som Vidner Landraad von Levetzau, Provst Göttig, Stenhugger Gebhardt fra Aabenraa og Gaardejer S. Johannsen fra Vollerup. Statsadvokaten androg paa 3 Maaneders Fængsel for hver af de 4 Kirkeældste og paa 6 Maaneder for Advokat Bekker. Dommen, som lød paa 1 Maaneds Fængsel for hver af de Kirkeældste, mens Advokat Bekker frikendtes, forkyndtes først den 15. Maj. Sagen indankedes og forhandledes i Septbr. ved Appellationsretten i Kiel. "Flensborg Avis« skriver den 23. Septbr.: Appellationsrettens Kendelse $i$ Tirsdags lød paa 3 Maaneder for Advokat Bekker og 1 Maaned for hver af de Kirkeældste. Formodentlig vil Sagen gaa til højeste Instans. Dette synes dog kun at 
have været Tilfældet med Advokat Bekkers Dom, for »Fædrelandet“ skriver den 11. Decbr.: I Onsdags stadfæstede Overtribunalretten i Berlin den Advokat Bekker af Appellationsretten i Kiel idømte Fængselsstraf paa 3 Maaneder.

Den 24. Januar skriver "Dannevirke», at Advokat Bekker fra Overstatsadvokaten i Kiel har faaet Befaling til at indfinde sig i Fængslet i Glückstadt forstkommende Tirsdag for at tiltræde de 3 Maaneders Fængselsstraf. Advokat Bekker har indgivet Andragende til Overtribunalet i Berlin om at faa Processen genoptagen, hvad saavel Kredsretten i Flensborg som Appellationsretten i Kiel har nægtet. Den 26. April hedder det i "Fædrelandet $\kappa$.

"Advokat Bekker fra Aabenraa vil om nogle Dage vende hjem fra Glückstadt, hvor han har afsonet de 3 Maaneders Fængselsstraf, som han i Fjor blev idømt af Appellationsretten i Kiel. Tre Maaneder i Fængsel er en lang Tid og langtfra nogen mild Straf, men alligevel synes Bekkers Foresatte at være af den Mening, at hans Optræden i Bjolderup-Sagen $\mathrm{m}$. $\mathrm{m}$. endnu ikke er straffet nok, thi $\mathrm{i}$ disse Dage har den saakaldte "Ehrenrath", en Domstol for Embedsmænd, meddelt ham, at der hos dem er anlagt Sag imod ham til Embedsfortabelse, og at der straks er bleven andraget paa hans Suspension. Bekker vil altsaa sandsynligvis allerede være eller dog med det første blive suspenderet fra sit Embede som Advokat, saa han, i det mindste indtil Sagen er bleven paadømt, hvilket vil ske den 18. Maj, fremdeles ikke kan drive sit Advokatur og derved vil komme til at lide store pekuniære Tab."

Den 18. Maj afholdtes denne "Aresret" i Kiel. Advokat Bekker idømtes Sagens Omkostninger, men frifandtes iøvrigt for videre Tiltale. Retten havde været sammensat af 5 Advokater, som var valgte af alle Sagførere i Slesvig og Holsten. Det Offentlige havde andraget paa, at Advokat Bekkers Notariats- og Sagførerbestalling skulde kasseres paa Grund af Delagtighed i Bjolderup Tavlehistorie. Kort efter sin Hjemkomst fra Fængslet i Glückstadt var Advokat Bekker bleven suspenderet, idet hans Notariatssegl og Protokoller blev ham fratagne.

Det Offentlige indankede Eresrettens Kendelse for Overtribunalretten i Berlin, som behandlede Sagen den 6. Oktbr. 1876. Statsadvokaten androg paa, at Advokat Bekker frakendtes sine 
Bestallinger som Advokat og Notar. Overtribunalretten gik dog ikke saa vidt, den tildelte ham en Bøde paa 1500,- Rmk. og Sagens Omkostninger. "Dannevirke" tilføjer: "Denne Bøde er vel at mærke for samme Sag, for hvilket han allerede har siddet 3 Maaneder i Fængsel. Det synes at være en Ejendommelighed ved den preussiske Rettergang, at en Mand kan straffes flere Gange for samme Forseelse."

Suspensionen hævedes først i de første Dage af Novbr, en Maaned efter Overtribunalets "Frifindelsesdom». Den havde da varet $i$ over tre Fjerdingaar.

Det vil vel blive staaende som en uløst Gaade, hvordan man har kunnet gøre det muligt, at faa en lovkyndig Mand og anerkendt Advokat straffet, fordi han vejledede Kirkeforstanderskabet, der søgte Hjælp og Bistand hos ham i sin Nød, da Myndighederne trængte og forfulgte det.

Man kan jo ogsaa med nogen Ret spørge, hvordan det var muligt at faa de 4 Kirkeældste idømt Fængselsstraf, at faa dem dømt som almindelige Forbrydere ved et Par Tyskeres Intriger. Konsistoriet, som havde foranlediget Statsadvokaten til at rejse Sagen, hvad denne gjorde efter en Del Betænkeligheder (Dv. d. 16. 4. 75) vidste jo $i$ alt Fald senest den 19. Juni fra Ministeriet, at de Kirkeældste havde haft Ret. Selv om den første Domfældelse fandt Sted den 5. Maj, saa der havde været meget god Tid til før Forhandlingerne ved Appellationsretten at underrette Statsadvokaten om Sagens forandrede Stilling.

Om de Kirkeældstes Fængselsstraf fortæller »Dannevirke» den 8. Januar 1876:

"De fire Kirkeældste i Bjolderup, der i Anledning af Tavlesagen blev idømte hver en Maaneds Fængsel, er i Fredags den 7. ds. ankommen til Flensborg, hvor de er henviste til Fængslet bag Møllen.

Det er disse Mænd, som saa tappert forsvarede deres gamle Kirke mod at blive vansiret af en tysk Mindetavle, men tilsidst i deres patriotiske. Iver kom til at støde an mod den tyske Straffelov, som da ogsaa blev anvendt mod dem $i$ al sin Strenghed. Men den danske Sag i Bjolderup Sogn tager visselig ingen Skade af dette Martyrium, som Sognets bedste Mænd nu maa lide i en Maaned for deres varme Fædrelandskærlighed «. 
Den 7. Februar blev de saa losladt af Fængslet igen. De blev (ifølge "Flensborg Avis« den 10. 2.) ført langs Hovedgaden til Statsadvokatens Kontor, hvor de fik deres endelige Demission. De maatte selv bære deres Bagage, deriblandt en Del Sengetøj, som de havde haft med hjemmefra, hele Vejen, og det tillodes dem ikke at benytte en Vogn, som en flensborgsk Dame havde stillet til deres Raadighed.

Min Hjemmelsmand, Hans Lorensen fra Bolderslev, har fortalt mig om Hjemrejsen, at en rig Slagterenke $i$ Flensborg havde stillet sin Karet til Raadighed for de Kirkeældste for at køre dem fra Fængslet til Banegaarden. Dog dette formentes dem af Fængselsmyndighederne. Kusken havde faaet Ordre til, hvis dette skulde ske, at køre lige bagefter dem for at vise Flensborgerne, at Vognen var der, men bare ikke maatte benyttes. En anden Hjemmelsmand, Mathias Knudsen i Hjolderup, den gamle Math. Knudsens Sønnesøn, har fortalt mig, at Overleve-

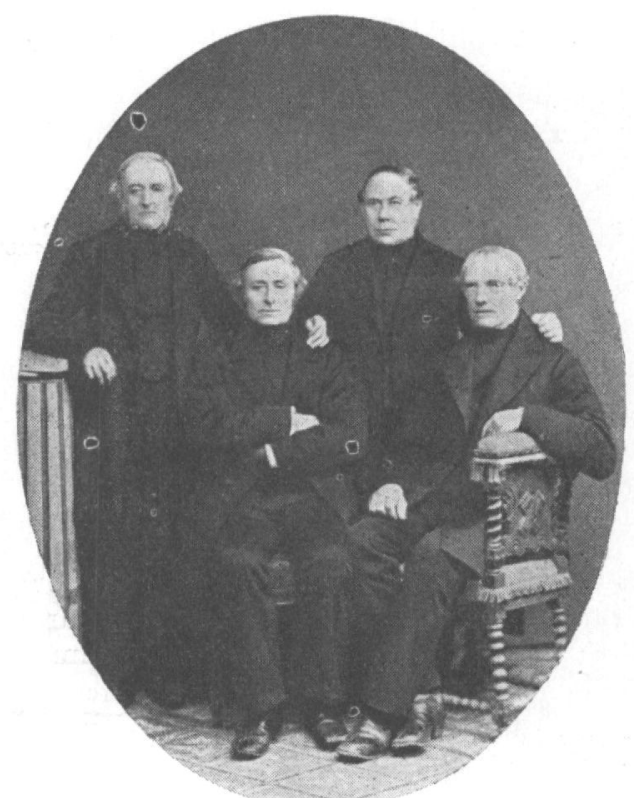

De fire Kirkeceldste. ringen Ira hans Bedstefader gik ud paa, at de Kirkeældste havde kart i Karet til Banegaarden, (det kan jo godt være sket fra Statsadvokatens Kontor, hvor de fik deres endelige Demission). Men flensborgske Borgere havde været saa begejstrede for de ubøjelige, stoute Bønder, at de havde spændt Hestene fra Vognen og havde trukket Vognen i Triumf til Banegaarden. 
De 4 Kirkeældste kørte nu ikke med Toget til Bolderslev, men steg ud i Tinglev, hvor de blev hentet af deres Venner, for at Baneforvalter Petersen i Bolderslev ikke skulde mærke deres Hjemkomst. Vogntoget kørte op til Jørgen Jørgensens Gaard i Bolderslev, hvor en stor Vennekreds var samlet for at fejre deres Hjemkomst og give dem Oprejsning for den Tort, som Myndighederne havde tilføjet dem. Der overraktes hver af dem en kostbar Bibel med vedkommendes Navn trykt paa Titelbladet som en Tak fra Menigheden for deres Indsats i Kampen mod overmægtige Myndigheder og for deres Bestræbelse paa at holde Kirken ren for Tyskernes politiske Indgreb.

Der er selvfølgelig bleven holdt Taler for Hædersgæsterne ved Festen, der jo iøvrigt maatte have et absolut privat Præg, da den afholdtes $\mathrm{i}$ et privat Hjem. Ikke desto mindre patrouillerede Gendarmen frem og tilbage ude paa en offentlig Sti, som førte direkte forbi Vinduerne, og om Aftenen luskede han omkring ved Gaarden for at opsnappe Brudstykker af Talerne. At Festen har faaet et Eftersmæk, kan man se af en Artikel i "Fædrelandet" den 2. Marts:

"Bjolderup Affæren er ikke afsluttet endnu. Da de 4 Kirkeældste kom hjem fra Fængslet i Flensborg, samledes Sognefolkene med dem i den enes, Jørgen Jørgensens Gaard, for at hilse paa dem. Dette har givet Anledning til en Række Forhør i Aabenraa, saa man antager, at for hvad der ved denne Sammenkomst er bleven sagt, vil der blive anlagt Sag mod Vedkommende for Overtrædelse af Foreningsloven, efterdi "Forsamlingen" hos Jørgen Jørgensen ikke har været anmeldt for Politiet. En slig Udlægning af Foreningsloven dens Anvendelse paa private Selskaber - der var ganske almindelig i Preussen for en Snes Aar siden imod de Liberale, der nu er ved Roret, har man endnu ikke gjort Bekendtskab med i Nordslesvig, men det er ingen Skade til at lære de forskellige Sider af det preussiske Væsen at kende, desto bedre kan man vurdere det."

Der er dog formodentlig ikke kommen noget ud af disse Forhør, ialtfald ved man intet om det nu, og Akter forefindes ikke herom.

Festen skulde have været afholdt i Bolderslev Østerkro, som min Fader havde overtaget i Forpagtning et Par Aar i Forvejen. Da Herredsfoged Jensen erfarede dette, henvendte han 
sig straks til min Fader med en "velment Advarsel " mod at give Hus til den paatænkte Fest. Min Fader raadslog med gode Venner, hvad han skulde gøre. Resultatet blev, at man opdagede, at Gulvet i Skænkestuen tiltrængte at fornyes, det maatte saa ske netop i de Dage, da Festen fandt Sted. Til min Faders Undskyldning vil jeg sige, at han lige havde begyndt sin Virksomhed som Bygmester, og han har vel ikke turdet vove at komme altfor skarpt paa Kant med Myndighederne. Dette har ialtfald ikke paa nogen Maade skadet hans Venskab med den Kirkeældste Jørgen Jørgensen, som stadig blev en god Ven af mit Hjem, han var min Gudfader.

Den 6. Decbr. 1878 valgtes Jørgen Jørgensen igen til Kirkeældste. Dette satte paany Baneforvalter Petersen i Affekt. Han sendte Gendarmen ud til Landraaden med Melding om, at man i Bjolderup saa sandelig havde tilladt sig at genvælge den i sin Tid afsatte Kirkeældste Jørgen Jørgensen. Akterne i Aabenraa fortæller herom følgende:

"Slot Brunlund den 12. Decbr. 1878. Fodgendarm Gutjahr melder, at, som han har hørt af Baneforvalter Petersen i Bolderslev, er Gaardejer Jørgen Jørgensen, som for et Par Aar siden paa Grund af Mindetavlerne var bleven afskediget af Kirkeforstanderskabet, nu bleven valgt igen, og hans Valg er allerede bleven bekendtgjort af Præsten fra Prædikestolen. Til Vitterlighed: W. C. von Levetzau.»

Dette interessante Aktstykke fortsætter:

"Aabenraa den 12. Decbr. 1878. Genvalg af Jørgen Jørgensen var den Gang af Konsistoriet kun forbudt for det forestaaende Valg. Efter den nu gældende Menighedsforfatning paahviler Prøven af Valget Kirkeforstanderskabet, og Forkyndelsen af Valg kan derfor ske, uden at der skal ske Melding herom til Kirkevisitatoriet.

1) Gendarm Gutjahr skal lejlighedsvis underrettes om Sagens Forhold. 2) ad Akter Bjolderup Kirke.

Det kgl. Kirkevisitatorium

W. C. von Levetzau. Göttig."

Petersen fik altsaa ikke megen Glæde af sin sidste Daad i denne Affære.

Gamle Jørgen Nymand, som han altid kaldtes, var ikke blot en dygtig Mand, men ogsaa en klog og forstaaende Mand, som Folk gerne søgte til i deres store og smaa Sorger, og de gik vist aldrig forgæves, han hjalp gerne baade med Raad og Daad, og 
han havde en aaben Haand, hvor Hjælpen tiltrængtes. Det var ikke bare i Bolderslev By, dette var Tilfældet, men Gaardejer Tøge Tøgesen i Perbøl, gamle Degn Tøgesens Søn, har fortalt mig, at gamle Jørgen Nymand hver Søndag efter Gudstjenesten kom ind paa Degnegaarden, hvor han i deres Storstue en Stunds Tid tog imod Folk fra Sognet, som vilde søge Raad hos ham. De vidste, her kunde han træffes. Det var, som naar en Konge gav Audiens. Han var Bykonge i allerbedste Forstand. Jeg har medtaget dette lille Billede af gamle Jørgen Nymand, ikke for at fremhæve ham for de tre andre Kirkeældste, men fordi han var den eneste, som jeg har kendt personlig, og for at vise, at det var af den Slags Folk, Konsistoriet i Kiel og Provsten og Landraaden i Aabenraa lod sætte i Fængsel, fordi de vilde værne deres Kirke mod uberettiget Indgreb. Selvfølgelig har de andre tre $\mathrm{i}$ enhver Henseende staaet værdig ved Jørgen Nymands Side. Han døde den 6. Septbr. 1890, 73 Aar gammel.

\section{Jes Sarup.}

NB. Ved Festen for de Kirkeældste blev sunget en Sang, som en jydsk Bondekarl, der tjente hos Hans Lausen i Bolderslev, havde skrevet. Forfatteren følte sig saa usikker under prøjsisk Styre, efter at han havde begaaet Sangen, at han samme Nat, som Festen holdtes, hemmelig forlod sin Plads og rejste tilbage til Jylland. Gaardejer Andreas Knudsen fra Raved kunde huske de to forste Vers af den, som han har citeret for mig:

Velkommen hjem, I Gæve, Fra Fængslets Ensomhed

Til Eders Venner kære, ()g hjemmelige Færd.

Fra Fængslets skumle Morke

Vi glade Eder ser.

Gid med usvækket Styrke

Vi samles alle her.

Fordi I Mænd, saa kære

For Kirkens Skyld I led, Vil Gud vist med Jer være

Og værne om Jer Fred 


\section{Han være vil Jer Støtte \\ Og Kirkens Værn og Skjold, Naar I den kækt beskytter \\ Mod Overlast og Vold.}

Titelbladet i den Bibel, som blev overrakt de enkelte Kirkeældste ved Festen, viste den enkelte Kirkeældstes Navn. Her gengives Math. Th. Knudsens:

\section{Til}

\section{KIRKE ELDSTE MATHIAS TH. KNUDSEN}

\section{i}

\section{Jollerup}

fra B jolderup Menighed med Tak til ham og hans Slægt, til Minde om, hvad han gjorde og leed for Menigheden.

I Menighedens $\mathrm{Navn}$.

G. C. Knudsen. Iv. Jørgensen. J. Jørgensen. G. C. Strube. P. Lorensen. H. C. Strube.. B. Jensen.

C. C. Schmidt. Jes Hansen. I. H. Thomsen. H. Nissen. Jens Paulsen.

Ps. 115. 1.

Ikke os, Herre, men giv Dit Navn Ere for Din Miskundheds Skyld, for Din Sandheds Skyld. 